\title{
Proteases of haematophagous arthropod vectors are involved in blood-feeding, yolk formation and immunity - a review
}

\author{
Paula Beatriz Santiago 1, Carla Nunes de Araújo 1,2, Flávia Nader Motta ${ }^{1,2}$, Yanna Reis Praça $a^{1,3}$, Sébastien Charneau4, \\ Izabela M. Dourado Bastos ${ }^{1}$ and Jaime M. Santana ${ }^{1 *}$
}

\begin{abstract}
Ticks, triatomines, mosquitoes and sand flies comprise a large number of haematophagous arthropods considered vectors of human infectious diseases. While consuming blood to obtain the nutrients necessary to carry on life functions, these insects can transmit pathogenic microorganisms to the vertebrate host. Among the molecules related to the blood-feeding habit, proteases play an essential role. In this review, we provide a panorama of proteases from arthropod vectors involved in haematophagy, in digestion, in egg development and in immunity. As these molecules act in central biological processes, proteases from haematophagous vectors of infectious diseases may influence vector competence to transmit pathogens to their prey, and thus could be valuable targets for vectorial control.
\end{abstract}

Keywords: Proteases, Haematophagy, Digestion, Yolk formation, Immunity, Ticks, Triatomines, Mosquitoes

\section{Background}

Haematophagous arthropod vectors are spread worldwide. They are of medical and veterinary importance since their blood-feeding habit provides a scenario for the transmission of a variety of pathogens, including virus, bacteria, protozoans and helminths [1]. Although there are clinical differences among the diseases caused by these organisms, they share the tendency to coexist in low and middle-income countries. Additionally, for most of the infectious diseases transmitted by invertebrate vectors there are neither vaccines nor preventive treatments. Few chemotherapy drugs are available for the treatment with many serious adverse reactions and rapid emergence of resistant strains, generating social and economic losses in those countries. Chikungunya, Mayaro and Zika virus infections, Crimean-Congo haemorrhagic fever, dengue fever, Japanese encephalitis, Rift Valley fever, tick-borne encephalitis, West Nile fever, yellow fever, Lyme disease, plague, rickettsiosis, tularaemia, Chagas disease,

\footnotetext{
*Correspondence: jsantana@unb.br

${ }^{1}$ Laboratório de Interação Patógeno-Hospedeiro, Departamento de Biologia Celular, Instituto de Ciências Biológicas, Universidade de Brasília, Campus Universitário Darcy Ribeiro, Asa Norte, 70910-900 Brasília, DF, Brazil Full list of author information is available at the end of the article
}

leishmaniasis, malaria, sleeping sickness, lymphatic filariasis and onchocerciasis are all examples of vector-borne diseases with global impact on morbidity and mortality (Table 1) since they affect more than one billion individuals and cause over one million deaths every year [2].

Ecological factors are associated with vector dispersion to urban areas [3]. Ticks, triatomine bugs, mosquitoes, sand flies, tsetse and black flies are the main haematophagous arthropod vectors [2], which present different feeding habits. In ticks and triatomines, this habit is seen in both female and male, and in all stages of development. Changing from one stage to the next requires at least one blood meal. On the other hand, only females of mosquitoes and sand flies require a blood meal to fulfil their need to complete the oogenesis process [4].

Vascular damage caused by the haematophagous bite during the repast triggers physiological defence responses in the host that are mainly determined by three important events: haemostasis, immunity and inflammation. To accomplish a continued blood flow, a saliva array of pharmacologically active biomolecules, as antihaemostatic, anti-inflammatory and immunomodulatory compounds, is injected into the bite site [5-9]. Within this context, different pathogens can be transmitted by 
Table 1 Vector-borne diseases

\begin{tabular}{|c|c|c|c|c|}
\hline Disease & Pathogen & Estimated number & Major distribution & Major vectors \\
\hline Chikungunya & $\begin{array}{l}\text { Chikungunya virus: } \\
\text { Alphavirus (Togaviridae) }\end{array}$ & 37,480 (Americas, 2015) & $\begin{array}{l}\text { Africa, the Americas, Asia, } \\
\text { Europe }\end{array}$ & Aedes spp. \\
\hline Mayaro fever & $\begin{array}{l}\text { Mayaro virus: Alphavirus } \\
\text { (Togaviridae) }\end{array}$ & 197 cases $(2015)^{a}$ & South America & $\begin{array}{l}\text { Haemagogus } \\
\text { janthinomys }\end{array}$ \\
\hline Zika & $\begin{array}{l}\text { Zika virus: Flavivirus } \\
\text { (Flaviviridae) }\end{array}$ & No official WHO report ${ }^{b}$ & $\begin{array}{l}\text { Africa and Asia (60s to } 80 \mathrm{~s}) ; \\
\text { Americas, Western Pacific }\end{array}$ & Aedes spp. \\
\hline $\begin{array}{l}\text { Crimean-Congo } \\
\text { haemorrhagic fever }\end{array}$ & $\begin{array}{l}\text { Crimean-Congo virus: } \\
\text { Nairovirus (Bunyaviridae) }\end{array}$ & Regional outbreaks & $\begin{array}{l}\text { Africa, the Balkans, the Middle } \\
\text { East, Asia }\end{array}$ & Hyalomma spp. \\
\hline Dengue & $\begin{array}{l}\text { Dengue virus, serotypes } \\
\text { DEN 1-4: Flavivirus } \\
\text { (Flaviviridae) }\end{array}$ & $\begin{array}{l}3.2 \text { million (Americas, South-East } \\
\text { Asia and Western Pacific, 2015) }\end{array}$ & $\begin{array}{l}\text { Africa, the Americas, Eastern } \\
\text { Mediterranean, South-East } \\
\text { Asia, the Western Pacific }\end{array}$ & $\begin{array}{l}\text { Aedes aegypti and } \\
\text { Aedes albopictus } \\
\text { (secondary vector) }\end{array}$ \\
\hline Japanese encephalitis & $\begin{array}{l}\text { Japanese encephalitis virus: } \\
\text { Flavivirus (Flaviviridae) }\end{array}$ & 68,000 (Asia, estimated per year) & $\begin{array}{l}\text { South-East Asia and Western } \\
\text { Pacific regions }\end{array}$ & Culex spp. \\
\hline Rift Valley fever & $\begin{array}{l}\text { Rift Valley virus: Phlebovirus } \\
\text { (Bunyaviridae) }\end{array}$ & Regional outbreaks & Africa, Arabian Peninsula & Aedes spp. \\
\hline Tick-borne encephalitis & $\begin{array}{l}\text { Tick-borne encephalitis virus: } \\
\text { Flavivirus (Flaviviridae) }\end{array}$ & $10,000-12,000$ (estimated per year) & $\begin{array}{l}\text { Europe, northern China, } \\
\text { Mongolia, the Russian Federation }\end{array}$ & Ixodidae \\
\hline West Nile fever & $\begin{array}{l}\text { West Nile virus: Flavivirus } \\
\text { (Flaviviridae) }\end{array}$ & Regional outbreaks & $\begin{array}{l}\text { Africa, Europe, the Middle East, } \\
\text { North America and West Asia }\end{array}$ & Culex spp. \\
\hline Yellow fever & $\begin{array}{l}\text { Yellow fever virus: Flavivirus } \\
\text { (Flaviviridae) }\end{array}$ & 200,000 (estimated per year) & Africa, Central and South America & $\begin{array}{l}\text { Aedes and } \\
\text { Haemagogus }\end{array}$ \\
\hline Lyme disease & $\begin{array}{l}\text { Borrelia burgdorferi } \\
\text { (Spirochaetaceae) }\end{array}$ & $25,359(\text { USA, 2014) })^{c}$ & $\begin{array}{l}\text { Areas of Asia, north-western, } \\
\text { central and eastern Europe, USA }\end{array}$ & Ixodidae \\
\hline Plague & $\begin{array}{l}\text { Yersinia pestis } \\
\text { (Enterobacteriaceae) }\end{array}$ & $783(2013)$ & $\begin{array}{l}\text { Asia and South America (until 90s); } \\
\text { Africa }\end{array}$ & Xenopsylla cheopis \\
\hline Rickettsiosis & $\begin{array}{l}\text { Species of the genera: } \\
\text { Rickettsia, Orientia, Ehrlichia, } \\
\text { Neorickettsia, Neoehrlichia and } \\
\text { Anaplasma }\end{array}$ & Millions of cases annually ${ }^{c}$ & Americas, Europe, Asia, Africa & $\begin{array}{l}\text { Ticks, lice and } \\
\text { fleas }\end{array}$ \\
\hline Tularaemia & $\begin{array}{l}\text { Francisella tularensis } \\
\text { (Francisellaceae) }\end{array}$ & Regional outbreaks & $\begin{array}{l}\text { North America, eastern Europe, } \\
\text { China, Japan, Scandinavia }\end{array}$ & $\begin{array}{l}\text { Dermacentor spp., } \\
\text { Chrysops spp., } \\
\text { Amblyomma } \\
\text { americanum }\end{array}$ \\
\hline $\begin{array}{l}\text { American } \\
\text { trypanosomiasis } \\
\text { (Chagas disease) }\end{array}$ & $\begin{array}{l}\text { Trypanosoma cruzi } \\
\text { (Trypanosomatidae) }\end{array}$ & 6 to 7 million & Central and South America & Triatominae \\
\hline $\begin{array}{l}\text { African trypanosomiasis } \\
\text { (sleeping sickness) }\end{array}$ & $\begin{array}{l}\text { Trypanosoma brucei } \\
\text { (Trypanosomatidae) }\end{array}$ & $3,796(2014)$ & sub-Saharan Africa & Glossina spp. \\
\hline Leishmaniasis & $\begin{array}{l}\text { Leishmania spp. } \\
\text { (Trypanosomatidae) }\end{array}$ & $\begin{array}{l}900,000-1.3 \text { million } \\
\text { (estimated per year) }\end{array}$ & $\begin{array}{l}\text { Americas, North Africa-Eurasia, } \\
\text { East Africa, South-East Asia, } \\
\text { Mediterranean basin }\end{array}$ & $\begin{array}{l}\text { Plebotomine } \\
\text { sand flies }\end{array}$ \\
\hline Malaria & $\begin{array}{l}\text { Plasmodium spp. } \\
\text { (Plasmodiidae) }\end{array}$ & 214 million (estimated, 2015) & $\begin{array}{l}\text { sub-Saharan Africa, Asia, Latin } \\
\text { America, the Middle East }\end{array}$ & Anopheles spp. \\
\hline Lymphatic filariasis & $\begin{array}{l}\text { Wuchereria bancrofti } \\
\text { (Onchocercidae) }\end{array}$ & 120 million (2000) & $\begin{array}{l}\text { Angola, Cameroon, Côte d'Ivoire, } \\
\text { Democratic Republic of the Congo, } \\
\text { India, Indonesia, Mozambique, } \\
\text { Myanmar, Nigeria, the United } \\
\text { Republic of Tanzania }\end{array}$ & Culex spp. \\
\hline Onchocerciasis & $\begin{array}{l}\text { Onchocerca volvulus } \\
\text { (Onchocercidae) }\end{array}$ & 25 million $^{c}$ & $\begin{array}{l}\text { sub-Saharan Africa, Yemen, Brazil, } \\
\text { Venezuela }\end{array}$ & Simulium spp. \\
\hline Babesiosis & $\begin{array}{l}\text { Babesia spp. } \\
\text { (Babesiidae) }\end{array}$ & $1,762\left(\right.$ USA, 2013) ${ }^{C}$ & EUA & Ixodidae \\
\hline
\end{tabular}

Data from World Health Organization (WHO) web page available in <http://www.who.int/en/>. Accessed on September 15, 2016

a Data from Brazilian Health Ministry

${ }^{b}$ Recent outbreak in South and Central America but no official count of the number of people infected was reported by WHO

${ }^{c}$ Data from Centers for Disease Control and Prevention (CDC) web page available in <http://www.cdc.gov>. Accessed on September 15,2016 
vector saliva [10, 11]. Depending on each feeding habit, after achieving the necessary fluidity, the haematophagous can consume a large amount of blood in a single meal, and proceed to digestion [4]. Various proteases are involved in the blood meal digestion as a means to obtain the necessary energy for vital biological processes, guaranteeing the haematophagous arthropods' survival, biological development and reproduction [11].

Proteases are enzymes that hydrolyse (a) peptide bond(s) in amino acid residue sequences; if such catalysis occurs in internal peptide bonds of a protein, they are called endopeptidases. However, when cleavage of a peptide bond takes place at the $\mathrm{N}$ - or $\mathrm{C}$-terminal of a polypeptide chain, those enzymes are named exopeptidases. Protease classification involves the clustering of related sequences into families. Currently, there are seven main different families of proteases: aspartic, cysteine, glutamic, metallo, serine, threonine peptidase and asparagine lyase, all grouped according to the molecular composition of their active sites [12]. The clans represent one or more families that have evolutionary relationships evidenced by their tertiary structures or, when no tertiary structures are available, by the order of amino acid residues in the catalytic site and/or by common sequences around it [12]. Each clan is identified by two letters where the first represents the catalytic type of the families. There are three additional letters to assign a clan: P, for peptidases of mixed catalytic type; U, for peptidases of unknown catalytic type; and I, for inhibitors that are proteins. A clan identifier example is PA, which contains both serine $\mathrm{PA}(\mathrm{S})$ and cysteine peptidases $\mathrm{PA}(\mathrm{C})$. Regarding the family identification, it contains a letter representing the peptidase catalytic type together with a unique number [12]. For instance, $\mathrm{S} 1$ is the family of trypsin and chymotrypsin that also belongs to the $\mathrm{PA}(\mathrm{S})$ clan. Another clan example is CA, which contains several families of cysteine peptidases with structures like that of papain [12]. In this clan, $\mathrm{C} 1$ is the family of cathepsin B and L, peptidases that may act in the digestive vacuoles of protozoa and/or in the lysosomal system of eukaryotic cells [13].

Proteolytic enzymes may be synthesized as zymogens (inactive precursors) or as inactive forms bound to natural inhibitors to prevent unwanted protein degradation as well as to facilitate spatial and temporal organization of proteolytic activity [14]. Zymogen conversion to the active enzyme occurs by limited proteolysis and removal of an activation segment from its tertiary structure within an appropriate subcellular compartment or at the extracellular environment. Proteolysis of the activation segment may be performed by another peptidase or by autocatalysis, requiring, for instance, a drop in $\mathrm{pH}$ [14]. In this review, we highlight the functions of haematophagous arthropod proteases in blood-dependent biological processes, with an emphasis on their roles in vector biology.

\section{The role of arthropod vector proteases in blood dependent processes \\ Haematophagy}

Haematophagous arthropod vectors tend to take large blood meals, reducing the number of host visits and ensuring a supply of nutrients for a long period [4]. The blood-feeding habit can both occur from haemorrhagic pools that accumulate in the tissues following skin lacerations (pool feeders, as sand flies and ticks) or directly from a cannulated venule or arteriole (vessel feeders, as triatomines and mosquitoes) [15].

Haemostasis aims to restore vascular architecture and prevent blood loss leading to vasoconstriction, platelet aggregation and clotting [16, 17]. These would disrupt feeding and bleeding. Haematophagous saliva is injected at the bite site continuously during probing and ingestion phases to recognize and neutralize/modulate molecules involved in critical haemostatic pathways [17-20]. Among anti-haemostatic mechanisms, there is a variety of salivary natural protease inhibitors, pointing to the diverse cocktail arthropods produce against host proteases [21-24].

Advances in transcriptomic approaches have made it possible to analyse in a deeper insight the biochemical complexity of the saliva from many haematophagous arthropods, unravelling coding sequences for salivary gland proteases [25-36]. However, these sequences are not a guarantee of salivary protein expression, and few have been characterized so far [37]. From our experience, the saliva of triatomine bugs displays low proteolytic activities, tested by in-gel zymography or saliva direct incubation with fluorogenic substrates (unsubmitted).

\section{Digestion}

Proteins represent about 95\% of the blood [4], from which albumin and haemoglobin $(\mathrm{Hb})$ comprise over $80 \%$ of the total protein content [38]. Consequently, the haematophagous arthropods require proteases as the main enzymes in the midgut to process blood meal digestion $[4,38]$.

The blood meal is placed in the gut lumen, and it is usually separated from the epithelium by an extracellular semipermeable layer, known in some species as peritrophic matrix [4]. In insects, the architecture of the gut is usually a simple tube constituted of one layer of epithelium resting on a continuous basal lamina. There are functional variable sections in the gut among the different insect orders, but generally a uniform pattern can be observed. The anterior segment receives the blood meal and displays specializations consistent with the abilities to post-feeding distension, ion and water regulation to dehydration of blood, and carbohydrate digestion; while 
the posterior segment is often responsible for the synthesis and secretion of digestive proteases to digest the meal [39, 40]. The tick midgut consists of a central stomach that acts as a storage organ. Histologically, the lumen is surrounded by a thin epithelial layer and a thin outer layer of muscle fibers [11, 41].

Haematophagous arthropod vectors can be divided in two groups based on the different strategies to process the blood digestion [38]. In insects, midgut cells synthesize and secret digestive proteases in the lumen, typically via secretory vesicles or other small secretory structures placed near the base of the microvilli, where extracellular digestion occurs generating peptides, which are then absorbed by the epithelial cells [4, 39] In haematophagous insects the proteolytic network involved in midgut protein digestion is composed by serine proteases, mainly trypsins, with chymotrypsins and carboxypeptidases playing a supplementary role (Fig. 1). In this group, the triatomines are an exception as they use cathepsin and aspartic proteases [4].

In ticks, the digestion process occurs intracellularly through heterophagy by midgut cells [41]. Albumin is taken non-specifically by endocytosis into small acidic vesicles, while the endocytosis of $\mathrm{Hb}$ by digestive cells would be mediated by specific receptors and addressed to large digestive vesicles [42, 43]. Although the internalization of albumin and $\mathrm{Hb}$ by digestive cells occur by distinct routes, the proteolytic system that controls the albuminolytic and haemoglobinolytic pathways is the same [38]. A multi-enzyme model for $\mathrm{Hb}$ degradation was proposed in Ixodes ricinus. Inside the acidic digestive vesicle, the degradation pathway is initiated by cysteine and aspartic endopeptidases (cathepsin L, legumain and cathepsin $\mathrm{D})$, generating large peptides fragments $(8-11 \mathrm{kDa})$, followed by the action of cathepsins $B$ and $\mathrm{C}$ exopeptidases, generating smaller peptides $(2-7 \mathrm{kDa})$. Finally, serine carboxypeptidase (SCP) and leucine aminopeptidase (LAP) might participate in the liberation of dipeptides and free amino acids. It has been suggested that the final stages of $\mathrm{Hb}$ degradation take place both in and outside of the digestive vesicles, in the cytosol. The heme moiety released forms aggregates that are accumulated in the hemosomes. The $\mathrm{Hb}$ specific receptor probably evolved as an adaptation to avoid the toxicity of the heme (Fig. 1) [11, 44, 45].

\section{Yolk formation}

A blood meal provides the necessary resources for haematophagous arthropods to produce their eggs [4]. The yolk precursor protein vitellogenin $(\mathrm{Vg})$ is, in arthropods, synthesized in the fat body and then secreted into the haemolymph. After being uptaken by oocyte coated vesicles, the Vg suffers dissociation and a crystallization process occurs in the endosome compartment, forming

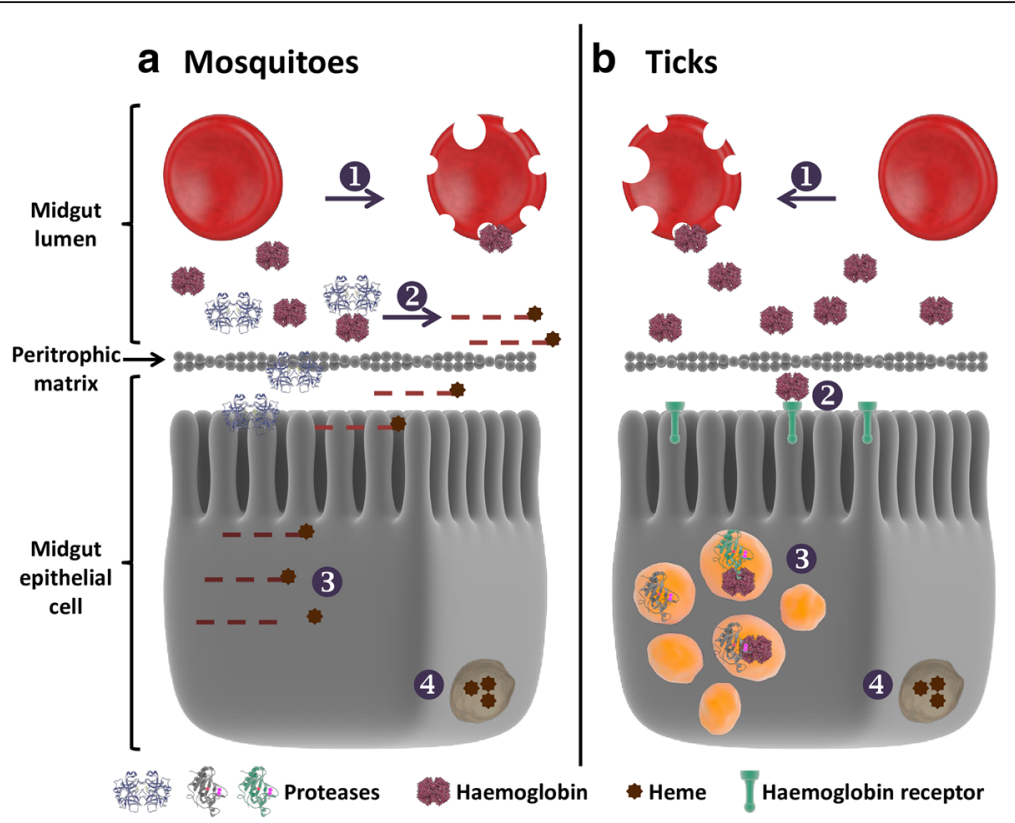

Fig. 1 Haemoglobin digestion in mosquitoes and ticks. a Host erythrocytes undergo lysis and release haemoglobin (Hb) and other proteins in the lumen of the midgut (1). In mosquitoes, proteases are secreted in the gut lumen for initial Hb extracellular digestion (2), generating peptides that will be further internalized and hydrolyzed in the epithelial cells (3). b In ticks, Hb is internalized by receptor-mediated endocytosis (2) and directed to large endosomal vesicles that fuse with lysosomes containing cysteine and aspartic proteases where it is degraded (3). Upon degradation of $\mathrm{Hb}$, free heme must be detoxified (4) 
the yolk body. Vitellogenin proteolysis generates vitellin (Vt) in lysosome-like organelles. The final mature yolk body containing the crystalline Vt form provides the energy to support embryo development, together with lipids and sugars [46].

The accumulation of yolk proteins is regulated by the developmental hormones juvenile hormone $(\mathrm{JH})$ and 20-hydroxyecdysona (20-HE), both found in low levels in young females. Once adults undergo eclosion, the level of $\mathrm{JH}$ rises and the fat body becomes responsive to signals that induce vitellogenesis [47]. The roles of $\mathrm{JH}$ also include the growth of terminal follicles and the development of oocyte competence for protein internalization [46].

Upon a blood meal, the JH level drops in haemolymph, while that of the egg development neurosecretory hormone $(\mathrm{EDNH})$ increases to stimulate the release of ecdysone by ovaries. The latter is a steroidal prohormone that is converted in $20-\mathrm{HE}$, the main regulator of vitellogenesis in the fat body. This hormone stimulates the expression of $\mathrm{Vg}$, which is secreted in the haemolymph and endocytosed by oocytes [47]. Besides the 20$\mathrm{HE}$, the nutrients consumed during a blood meal could also be a signal for vitellogenesis regulation by the fat body [48]. The hormonal regulated yolk formation steps are summarized in Fig. 2.

\section{Immunity}

All arthropods need to defend themselves against infectious pathogens. Their innate immune response has physical barriers that include the cuticle, gut, trachea, chemical barriers, and defender cells that allow welldeveloped humoral and cellular responses [49]. The humoral responses are accomplished by antimicrobial peptides, such as defensins, secreted by fat body, hemocytes and epithelial layer of the gut $[49,50]$.

Pathogen recognition occurs via soluble or transmembrane pattern recognition receptors (PRRs) that respond to pathogen-associated molecular patterns (PAMPs), resulting in antimicrobial peptides synthesis, enzymatic cascades that can induce coagulation of haemolymph, wound healing and melanin formation. In addition, it may also activate phagocytosis, encapsulation, nodulation and antiviral response. Our current view of the arthropods immune system is represented in Fig. 3. Three major arthropod signalling immune pathways involved in the humoral and cellular responses have been described: the Toll, the immunodeficiency (IMD), and the JAK-STAT [51]. Innate immune response is triggered upon activation of Toll and IMD pathways, inducing antimicrobial peptide gene expression [52]. The JAK-STAT pathway also exerts its activity against such pathogens as viruses [53], bacteria [54-56], and Plasmodium [55, 57].

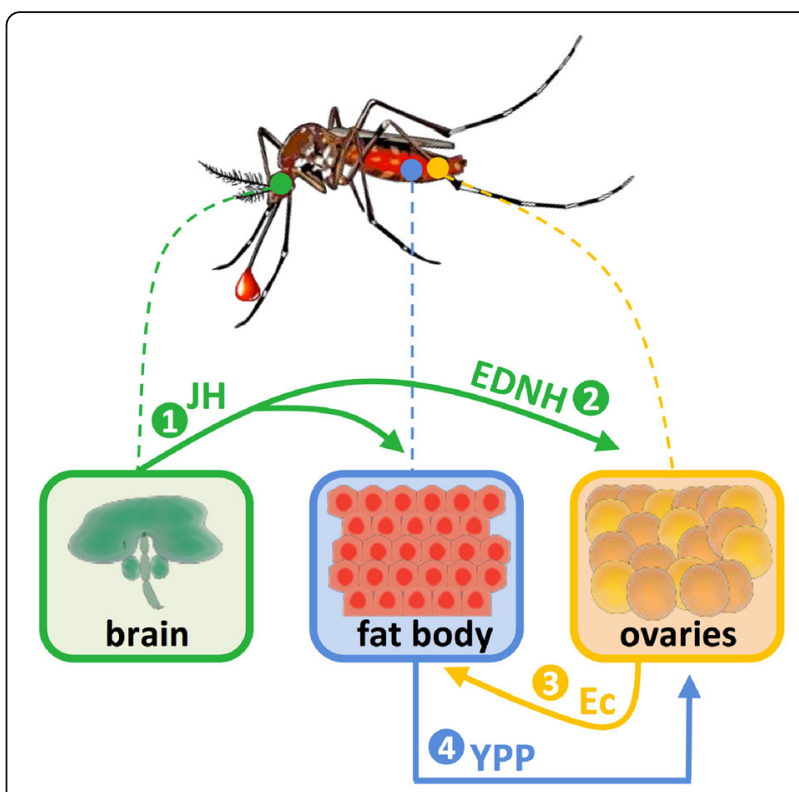

Fig. 2 Hormonal control of yolk formation. There are three invertebrate hormones that play major roles in yolk formation. Young females have a high level of juvenile hormone $(J \mathrm{H})$, which is produced by corpora allata located in the arthropod brain and acts on fat body and ovaries (1). Upon a blood meal, the JH level drops in haemolymph, and egg development neurosecretory hormone $(\mathrm{EDNH})$ (2) level increases to stimulate the release of ecdysone (Ec) (3) by ovaries that is converted in 20-hydroxyecdysona (20-HE) in the fat body. Together with 20-HE, the nutrients consumed during the blood meal stimulate the expression and secretion, by fat body cells, of yolk precursor proteins (YPP) (4) that are essential in vitellogenesis

Among the enzymatic cascades, the prophenoloxidase (proPO) one leads to melanisation of pathogens and damaged tissues, one of the major innate defence systems in invertebrates. Tiny amounts of PAMPs recognized by the PRRs ensure the activation of zymogenic proPO into active phenoloxidase $(\mathrm{PO})$ by a cascade of serine proteases. $\mathrm{PO}$ oxidizes tyrosine to dihydroxyphenilalanine and then to quinones, which are precursors of melanin and other toxic and reactive compounds. This process is controlled by specific protease inhibitors and by active $\mathrm{PO}$ in a complex manner aiming to avoid superfluous activation and production of cytotoxic compounds [51, 58, 59].

Finally, the presence of hypervariable PRRs in arthropods [60-62] with the ability to differently bind and recognize a range of microorganisms, microbial products, and multicellular parasites has shed some light on the possible existence of memory and specificity in arthropod immunity [62-64].

\section{Proteases from haematophagous arthropod vectors \\ In ticks}

The digestive proteolytic network from I. ricinus proposed by biochemical and genetic analyses indicated a 


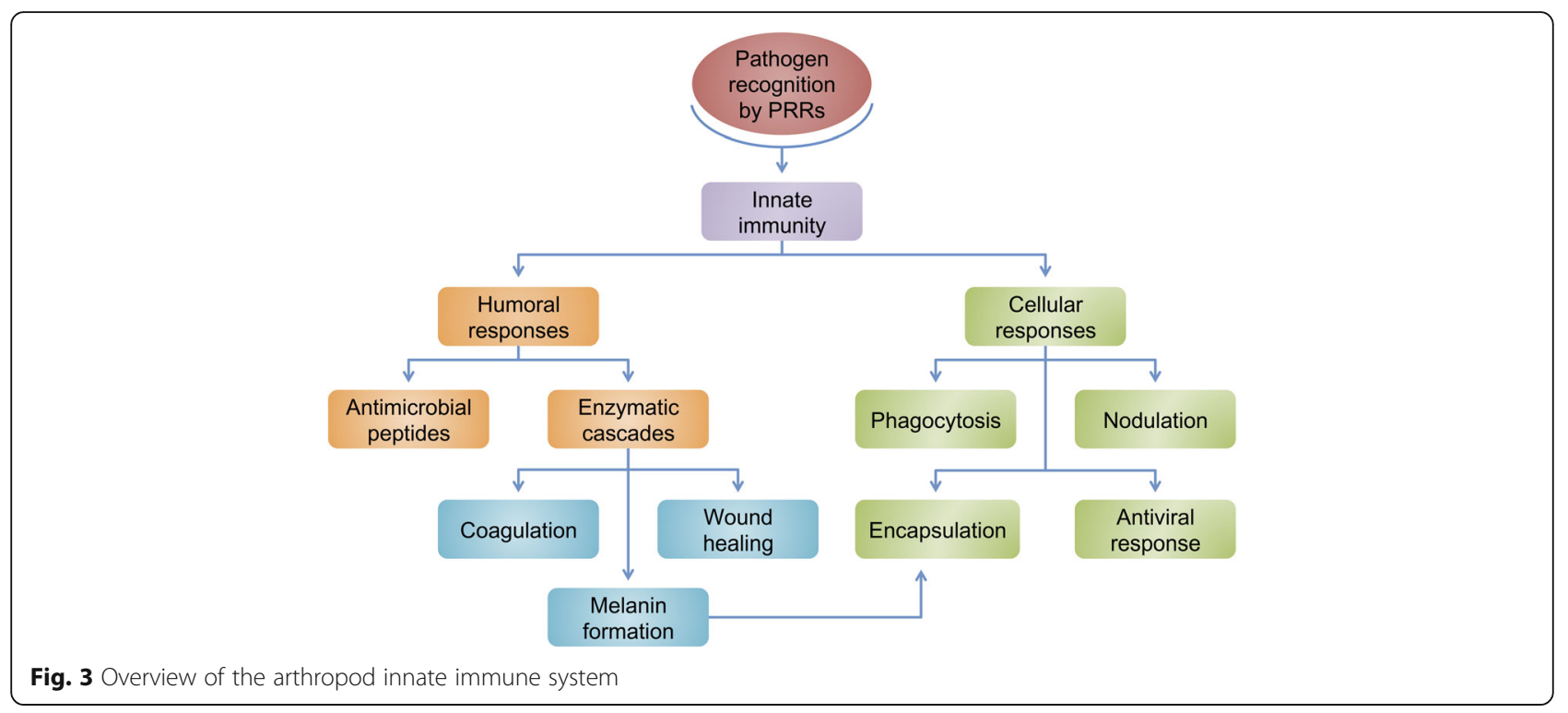

combination of four cysteine peptidase activities, cathepsins B (IrCB), C (IrCC), L (IrCL) and legumain (IrAE), and an aspartic peptidase activity, cathepsin D (IrCD) that operate together in haemoglobinolysis [65]. An insight into the gene transcription revealed that an increase in total haemoglobinolysis matches with the activity profiles of $\operatorname{IrCC}, \operatorname{IrAE}, \operatorname{IrCD}$ and $\operatorname{IrCB}$, being the last the most abundant protease of the pathway [66]. The endolysosomal localisation of IrCL1 was confirmed by immunolocalization [67]. The legumain $\operatorname{IrAE}$ is expressed only in the gut tissue and is localized within the peritrophic matrix, beyond in the digestive vesicles of gut cells. Ir AE hydrolyzed $\mathrm{Hb}$ to a predominant peptide of $4 \mathrm{kDa}$ [68].

Cathepsin L-like cysteine proteases have been reported in Haemaphysalis longicornis [69], HlCPL-A is upregulated during the repast and cleaves bovine $\mathrm{Hb}$ in a dose-dependent manner at $\mathrm{pH} 5.5$ [69]. Two other cathepsin L-like genes, HLCG-A and HLCG-B may also have important functions in the digestion of host $\mathrm{Hb}$ [70]. These cathepsin L-like cysteine activities are also present in Rhipicephalus (Boophilus) microplus tick crude midgut extracts [71-73], larvae [74, 75], and eggs [76]. The enzymes mediating these activities are named Boophilus microplus cathepsin L-like (BmCL1), R. microplus larval cysteine endopeptidase (RmLCE), and vittelin degrading cysteine endopeptidase (VTDCE), respectively. RmLCE is possibly the native form of the recombinant BmCL1 [74]. VTDCE is present in fat body, gut, salivary glands, ovary extracts, and haemolymph from partially or fully engorged females, suggesting it could have an extra ovarian origin, to be later internalized by oocytes [76]. Coexistence has been proposed between $\mathrm{VTDCE}$ and $\mathrm{Vg} / \mathrm{Vt}$ with no polypeptide cleavage during vitellogenesis [77]. Although VTDCE has been classified as a cathepsin L-like cysteine [76], a very low similarity was found between its deduced amino acid sequence (AFK78425.1) and any other cysteine endopeptidase. On the other hand, phylogenetic sequence analysis revealed that VTDCE is similar to some tick antimicrobial peptides [78]. Moreover, the presence of VTDCE significantly inhibits Staphylococcus epidermidis growth after a period of $24 \mathrm{~h}$. This is the first arthropod protease to be reported as an antimicrobial that is not correlated with its peptidase activity [78]. Finally, VTDCE, BmCL1 and RmLCE hydrolyse $\mathrm{Hb}$ and vitellin at acidic $\mathrm{pH}[73,74,76]$, and thus may have a fundamental role during tick development.

Taking into consideration the works mentioned above had been published before the $R$. (B.) microplus genome sequencing [79], we decided to carry out a deeper investigation to differentiate the sequence annotations and features of those three proteases. After a search into $R$. (B.) microplus genome database (GenBank: HM748961), ten different protein-coding genes for cathepsin $\mathrm{L}$ were identified, including BmCL1 (AAF61565.1); nevertheless, none of them codes for VTDCE. A comparative pair wise amino acid sequence alignment demonstrates a homology of, at least, $97 \%$ among the sequences (Table 2), that together with the fully identified active site residues (Additional file 1) may indicate $R$. (B.) microplus presents ten active cathepsin $\mathrm{L}$ isoforms. It is not possible to conclude that BmCL1 and RmLCE are the same isoform. However, a stage specific expression pattern may exist to guarantee the success of cathepsin L blood dependent processes in this tick.

Tsuji et al. [80] reported the molecular characterization of a cathepsin B-like named longipain from the midgut 
Table 2 Percentage of sequence identity between predicted Cathepsin L from Rhipicephalus (Boophilus) microplus after pairwise alignment performed with EMBOSS Needle

\begin{tabular}{|c|c|c|c|c|c|c|c|c|c|c|}
\hline Accession number & $\begin{array}{l}\text { AFQ } \\
98389.1\end{array}$ & $\begin{array}{l}\text { AFQ } \\
98385.1\end{array}$ & $\begin{array}{l}\text { AFQ } \\
98392.1\end{array}$ & $\begin{array}{l}\text { AFQ } \\
98386.1\end{array}$ & $\begin{array}{l}\text { AGK } \\
88363.1\end{array}$ & $\begin{array}{l}\text { AFQ } \\
98393.1\end{array}$ & $\begin{array}{l}\text { AFQ } \\
98390.1\end{array}$ & $\begin{array}{l}\text { AFQ } \\
98387.1\end{array}$ & $\begin{array}{l}\text { AAF } \\
61565.1 \\
\text { (BmCL1) }\end{array}$ & $\begin{array}{l}\text { AFQ } \\
98388.1\end{array}$ \\
\hline AFQ98389.1 & 100 & 99.4 & 98.5 & 98.2 & 98.2 & 98.2 & 98.2 & 98.5 & 98.2 & 98.2 \\
\hline AFQ98385.1 & & 100 & 99.1 & 98.8 & 98.8 & 98.8 & 98.8 & 99.1 & 98.8 & 98.2 \\
\hline AFQ98392.1 & & & 100 & 98.5 & 98.5 & 99.7 & 99.7 & 98.8 & 99.1 & 97.3 \\
\hline AFQ98386.1 & & & & 100 & 98.8 & 98.2 & 98.8 & 98.5 & 98.8 & 97.6 \\
\hline AGK88363.1 & & & & & 100 & 98.2 & 98.8 & 98.5 & 98.8 & 97.6 \\
\hline AFQ98393.1 & & & & & & 100 & 99.4 & 98.5 & 98.8 & 97.0 \\
\hline AFQ98390.1 & & & & & & & 100 & 99.1 & 99.4 & 97.6 \\
\hline AFQ98387.1 & & & & & & & & 100 & 99.1 & 97.9 \\
\hline AAF61565.1 (BmCL1) & & & & & & & & & 100 & 97.6 \\
\hline AFQ98388.1 & & & & & & & & & & 100 \\
\hline
\end{tabular}

epithelium of $H$. longicornis tick. It is specifically localized in the lysosomes and secreted into the intestinal lumen, following blood-feeding. Enzymatic assays with natural substrates indicate that longipain cleaves spectrin, an important component of erythrocyte membranes, but not Hb. Endogenous RNAi knockdown experiment suggests longipain activity in ticks is involved in feeding capacity and protection against parasites [80]. It is worth pointing out that this toxic effect may be direct and/or by means of the degradation of ingested proteins and peptides.

Legumains have been identified in the gut of $H$. longicornis, H. longicornis legumain 1 (HlLgm1) and H. longicornis legumain 2 (HlLgm2), by their ability to cleave Z-Ala-Ala-Asn-AMC at neutral pH [81, 82]. Differently, the optimal $\mathrm{pH}$ activity of IrAE legumain from $I$. ricinus is acidic [68]. HlLgm1 and HlLgm2 localize in the midgut epithelium and are upregulated during the blood-feeding process. However, HlLgm2 is expressed at a lower level than HILgm1 during digestion and there is no expression of HlLgm 2 above $96 \mathrm{~h}$ of feeding. The expression of HlLgm1 continues until full engorgement [82]. Moreover, the cleavage of bovine $\mathrm{Hb}$ by these legumains corroborates their role in the digestion of blood proteins [83]. Silencing of both genes by RNAi has revealed an extended feeding period, survival decrease, weight loss, delayed oviposition and reduced number of normal eggs. In addition, the epithelium of the gut shows, upon this condition, damage and disruption of normal cellular remodelling during feeding, resulting in luminal narrowing in silenced individuals [83].

The results of some very well designed experiments indicate that three cathepsin $\mathrm{D}$ isoforms ( $\operatorname{IrCD} 1-3)$ play central and distinct roles in the physiology and development of $I$. ricinus. IrCD1 is associated with the gut of partially engorged female ticks and is induced by feeding. This protease plays a haemoglobinolytic role in the digestive vesicles supported by immunolocalization and RNAi knockdown. IrCD2 isoform is expressed both in gut and salivary glands and its expression peak is observed in fully fed females. IrCD3 isoform is expressed in ovaries, and therefore is not related to haemoglobinolysis [84]. It has been proposed $\operatorname{IrCD} 1$ would act together with $\operatorname{IrAE}$, while $\mathrm{IrCD} 2$ could be secreted into the gut lumen to generate haemoglobin-derived antimicrobial peptides to preserve the blood meal. Finally, $\operatorname{IrCD} 3$ isoform would play a role in yolk protein degradation [85].

Other aspartic proteases have been shown to be also involved in yolk degradation [11]. Eggs of $R$. (B.) microplus express two aspartic proteases able to degrade $\mathrm{Vt}$ during embryogenesis: boophilus yolk cathepsin (BYC) and tick heme-binding protease (THAP). The activity of THAP seems to be regulated by heme molecule, and BYC also cleaves $\mathrm{Hb}$ [86-88]. Interestingly, a cathepsin $\mathrm{D}$ from this tick midgut (BmAP) may be responsible for the generation of antimicrobial peptides, suggesting that proteases play roles in immune response against parasite invasion [85, 89]. At last, a $H$. longicornis cathepsin D (longepsin) is highly expressed in the midgut after a blood meal and hydrolyses $\mathrm{Hb}$, besides being expressed in the salivary glands [90].

Some SPs have also been described in ticks. A multi-domain SP from $I$. ricinus named $\operatorname{IrFC}$ triggers coagulation of haemolymph in response to bacterial lipopolysaccharides, as its homolog in horseshoe crab. RT-PCR analysis has revealed that the IrFC mRNA is expressed in all life stages, and in adults it is present mainly in hemocytes as observed by indirect immunofluorescence microscopy, suggesting this enzyme has a function in tick immunity [91].

HLSG-1 and HLSG-2 SPs of the hard tick H. longicornis, which carries and transmits various pathogens [92], are blood meal-induced and expressed in the midgut, 
salivary glands as well as in other organs [93]. Another $H$. longicornis SP named HISP is expressed during development and is localized in the adult tick midgut. This protease contains the domains CUB (complement $\mathrm{C} 1 \mathrm{r} / \mathrm{C} 1 \mathrm{~s}$, Uegf, Bmp1) and LDL (low-density lipoprotein receptor class A domains), important at mediating extracellular protein-protein interactions [94-96]. Lower levels of HISP upon RNAi correlates well with the diminished capacity of ticks to degrade host erythrocytes, suggesting this enzyme is involved in haemolysis. Moreover, the recombinant protein rHISP also shows haemolytic activity in vitro in a dose-dependent manner [95]. Two other SPs studied, HISP2 and HISP3, are also localized in the midgut epithelial cells and lumen of adult ticks [97]. Silencing of these three SP genes together have resulted in body weight reduction, indicating they may form a proteolytic network for host $\mathrm{Hb}$ digestion in the midgut of ticks [97]. Finally, a carboxypeptidase-like SP, HISCP1, is found in the vacuoles of midgut endothelial cells of $H$. longicornis, and its upregulation is observed after a blood meal. Of interest, this protease is also able to cleave $\mathrm{Hb}$ [98].

Curiously, I. scapularis degradome (the full repertoire of proteases encoded by the genome) is mainly represented by metalloproteases ( 40\%) [99]. These are organized in 23 families, but functions in tick physiology are unknown for many of them. M12 family contains 14 enzymes that are believed to be involved in the regulation of blood-feeding. For instance, recombinant M12 AAP22067 mediates gelatinase and fibrinogenolytic activities [19], which are essential to maintain host blood in a fluid state during tick feeding. Metalloproteases make part of the midgut transcriptome from the hard tick Dermacentor variabilis [100], but their functions are unknown.

From the hard tick $H$. longicornis, an aminopeptidase member of the M17 family, HILAP, is upregulated by blood meal during initial feeding period and acts in the liberation of free amino acids in the cytosol of midgut epithelial cells [101]. In the sialotranscriptome of Haemaphysalis flava, metalloprotease genes supposed to be involved in modulating host haemostasis are over expressed in semi-engorged ticks, probably to maintain blood flow [102]. In $R$. microplus, RNAi silencing of metalloproteases affects average egg weight and oviposition rate [103]. In addition, three metalloprotease sequences from Amblyoma americanum show identity to annotated tick metalloproteases, and another shows identity to I. scapularis endothelin-converting enzyme (ECE) [104]. Endothelins are a family of potent vasoconstrictive peptides [105]. Thus, the role of ECE in haematophagous arthropod saliva might be the hydrolysis of endothelins to impair vasoconstriction.

Finally, tick salivary glands also express metalloproteases. From I. ricinus, two cDNAs coding homologous putative metalloproteases (Metis 1 and Metis 2) are expressed in salivary glands during feeding most likely to stimulate fibrinolysis. Indeed, knock-down by RNAi of Metis 1 and Metis 2 impairs blood meal completion [106]. The presence of specific antibodies against HLMP1, a recombinant tick reprolysin metalloprotease, results in lower feeding efficiency of $H$. longicornis in rabbits [107]. Protein sequences of the reproplysin family of metalloproteases from Ixodes persulcatus (Ip-MPs), Rhipicephalus sanguineus (Rs-MPs) and $R$. microplus (BrRm-MPs) have been found in the salivary glands of partially and fully fed female ticks, and may be required during tick feeding to manipulate host defences and support tick haematophagy [108].

In summary, cysteine-, serine-, aspartic- and metalloproteases have been described in ticks (Table 3 and Fig. 4). Notably cysteine and aspartic proteases are known for their role in tick digestion; however, as evidenced, they are distributed in different tissues where they have variable biological functions. Serine proteases are related to digestion and immunity, and metalloproteases have been described in the salivary glands and may act mainly on the vector-host interface to prevent haemostasis. Tick proteases play wide biological roles and their expressions and activities undergo tissue specific regulation.

\section{In triatomines}

There are a few reports on triatomine protease activities. In triatomine bugs, two cathepsin L-like proteases of Triatoma brasiliensis, TBCATL-1 and TBCATL-2 [109]; one of $R$. prolixus, RpCat [110], and another of T. infestans (CatL1) [111] have been characterized in the midgut of these species. TBCATL- 1 and TBCATL- 2 proteolytic activities have been detected in the posterior midgut by zymogram assay. Cathepsin B (CatB1) is present in gut extracts of T. infestans. CatL1 and CatB1 activities decrease during the first two days after feeding but increase to a maximum value at five and 10 days post feeding. A strong acidic peptidase activity found in the gut extract of $T$. infestans is possibly mediated by a cathepsin B. Although the molecular features and functional properties of the protein are unknown, the enzymatic activity is efficiently inhibited by CA-074, a specific cathepsin-B inhibitor [111]. The cathepsin B-like activity, which is present in the midgut of $R$. prolixus, is increased following a blood meal [112]. Indeed, trace amounts of cathepsin B are detected in the lysosome of $R$. prolixus midgut cells before feeding, but after blood sucking, cathepsin B localizes in a granular precipitate associated with this organelle, and may be released in the gut lumen [113].

A cathepsin D aspartic-like protease activity is detectable in the blood-sucking triatomine $R$, prolixus [114]. It has been suggested that Trypanosoma cruzi colonization of $R$. prolixus may modulate the expression of cathepsin $\mathrm{D}$ in the invertebrate since its activity is much higher on 
Table 3 Proteases from ticks

\begin{tabular}{|c|c|c|c|c|c|c|}
\hline Protease & Species & $\begin{array}{l}\text { Synthetic/Natural } \\
\text { substrate }\end{array}$ & Inhibitor & Localization & Role & Reference \\
\hline \multicolumn{7}{|l|}{ Cysteine } \\
\hline \multicolumn{7}{|l|}{ Cathepsin L } \\
\hline $\operatorname{IrCL} 1$ & Ixodes ricinus & Z-Phe-Arg-AMC & $\begin{array}{l}\text { E-64; Z-Phe- } \\
\text { Phe-DMK }\end{array}$ & Gut & Digestion & {$[67]$} \\
\hline HICPL-A & $\begin{array}{l}\text { Haemaphysalis } \\
\text { longicornis }\end{array}$ & Z-Phe-Arg-AMC & $\begin{array}{l}\text { Leupeptin; } \\
\text { Antipain; E-64 }\end{array}$ & Gut & Digestion & {$[69]$} \\
\hline HLCG-A; HLCG-B & H. longicornis & - & - & - & Digestion & [70] \\
\hline BmCL 1 & $\begin{array}{l}\text { Rhipicephalus } \\
\text { (Boophilus) microplus }\end{array}$ & $\begin{array}{l}\text { H-D-Val-Phe-Lys- } \\
\text { pNA; Hb }\end{array}$ & $\begin{array}{l}\text { E-64; Leupeptin; } \\
\text { Antipain }\end{array}$ & Gut & $\begin{array}{l}\text { Digestion; } \\
\text { yolk formation }\end{array}$ & {$[72,73]$} \\
\hline RmLCE & R. (B.) microplus & $\begin{array}{l}\text { AbzAla-Ile-Ala-Phe- } \\
\text { Phe-Ser-Arg-GIn- } \\
\text { EDDnp; N-Cbz- } \\
\text { Phe-Arg-AMC; Hb }\end{array}$ & $\begin{array}{l}\text { E-64; Pepstatin A; } \\
\text { Papain }\end{array}$ & Larve; gut & $\begin{array}{l}\text { Digestion; } \\
\text { yolk formation }\end{array}$ & {$[72,74]$} \\
\hline VTDCE & R. (B.) microplus & N-Cbz-Phe-Arg-AMC; Hb & $E-64$ & $\begin{array}{l}\text { Salivary glands; } \\
\text { gut; haemolymph; } \\
\text { fat body; ovary; eggs }\end{array}$ & $\begin{array}{l}\text { Yolk formation; } \\
\text { immunity; digestion }\end{array}$ & {$[76,77]$} \\
\hline \multicolumn{7}{|l|}{ Cathepsin B } \\
\hline $\operatorname{lrCB}$ & I. ricinus & - & - & Gut & Digestion & {$[44,66]$} \\
\hline Longipain & H. longicornis & Z-Phe-Arg-AMC & $E-64$ & Gut & Immunity & {$[80]$} \\
\hline \multicolumn{7}{|l|}{ Cathepsin C } \\
\hline $\operatorname{IrCC}$ & 1. ricinus & $\mathrm{Hb}$ & - & $\begin{array}{l}\text { Salivary glands; } \\
\text { gut; ovary }\end{array}$ & Digestion & {$[44,66]$} \\
\hline \multicolumn{7}{|l|}{ Legumain } \\
\hline IrAE & I. ricinus & Z-Ala-Ala-Asn-AMC & Azapeptidil & Gut & Digestion & {$[68]$} \\
\hline $\begin{array}{l}\mathrm{H} 1 \operatorname{Lgm} 1 ; \\
\mathrm{H} 1 \operatorname{Lgm} 2\end{array}$ & H. longicornis & Z-Ala-Ala-Asn-AMC & $\begin{array}{l}\text { lodoacetamide; } \\
\text { N- ethylmaleimide }\end{array}$ & Gut & $\begin{array}{l}\text { Haematophagy; } \\
\text { digestion; } \\
\text { yolk formation }\end{array}$ & {$[81-83]$} \\
\hline \multicolumn{7}{|l|}{ Aspartic } \\
\hline \multicolumn{7}{|l|}{ Cathepsin D } \\
\hline IrCD1 & I. ricinus & $\mathrm{Hb}$ & Pepstatin & Gut female & Digestion & {$[85]$} \\
\hline IrCD2 & I. ricinus & - & - & Gut; salivary glands & Digestion & {$[85]$} \\
\hline IrCD3 & I. ricinus & - & - & Ovaries & Yolk formation & {$[85]$} \\
\hline BYC & R. (B.) microplus & $\mathrm{Hb}$; Vitellin & - & Eggs & Yolk formation & {$[86,87]$} \\
\hline THAP & R. (B.) microplus & Abz-AIAFFSRQ-EDDnp & Pepstatin & Eggs & Yolk formation & {$[88]$} \\
\hline BmAP & R. (B.) microplus & - & - & Gut & Immunity & {$[89]$} \\
\hline Longepsin & H. longicornis & FITC-casein & Pepstatin A & Salivary glands; gut & Digestion & {$[90]$} \\
\hline \multicolumn{7}{|l|}{ Serine } \\
\hline \multicolumn{7}{|l|}{ Trypsin-like } \\
\hline $\operatorname{IrFC}$ & I. ricinus & - & - & Hemocytes & Immunity & [91] \\
\hline HLSG1; HLSG2 & H. longicornis & Bz-I-Arg-pNa; BSA & & Salivary glands; gut & $\begin{array}{l}\text { Haematophagy; } \\
\text { digestion }\end{array}$ & [93] \\
\hline $\begin{array}{l}\text { HISP; HISP 2; } \\
\text { HISP } 3\end{array}$ & H. longicornis & Bz-I-Arg-pNa; BSA & - & Gut & Digestion & {$[94,95,97]$} \\
\hline \multicolumn{7}{|c|}{ Carboxypeptidase-like } \\
\hline HISCP1 & H. longicornis & $\begin{array}{l}\text { Z-Phe-Leu; Pyr-Phe- } \\
\text { Leu-pNA }\end{array}$ & PMSF & Gut & Digestion & [98] \\
\hline \multicolumn{7}{|l|}{ Metallo } \\
\hline Is-degradome & Ixodes scapularis & - & - & - & Digestion & [99] \\
\hline
\end{tabular}


Table 3 Proteases from ticks (Continued)

\begin{tabular}{|c|c|c|c|c|c|c|}
\hline $\begin{array}{l}\text { Dv-coding } \\
\text { sequences }\end{array}$ & Dermacentor variabilis & - & - & Gut & Digestion & [100] \\
\hline $\begin{array}{l}\text { Hf-coding } \\
\text { sequences }\end{array}$ & Haemaphysalis flava & - & - & Salivary glands & Haematophagy & [102] \\
\hline Aa-sequences & Amblyomma americanum & - & - & Salivary glands & Haematophagy & [104] \\
\hline Metis 1; Metis 2 & 1. ricinus & - & - & Salivary glands & Haematophagy & [106] \\
\hline \multicolumn{7}{|l|}{$\mathrm{M} 12$} \\
\hline AAP22067 & I. scapularis & Gelatin & - & Salivary glands & Haematophagy & [19] \\
\hline \multicolumn{7}{|l|}{ M17 } \\
\hline HILAP & H. longicornis & - & - & Gut & Digestion & [101] \\
\hline \multicolumn{7}{|l|}{ Reproplysin } \\
\hline HLMP1 & H. longicornis & - & - & Salivary glands & Haematophagy & [107] \\
\hline Ip-MPs & Ixodes persulcatus & - & - & Salivary glands & Haematophagy & [108] \\
\hline Rs-MPs & Rhipicephalus sanguineus & - & - & Salivary glands & Haematophagy & [108] \\
\hline BrRm-MPs & R. (B.) microplus & - & - & Salivary glands & Haematophagy & [108] \\
\hline
\end{tabular}

days 1-3 after infection [114]. A similar result has been found in T. infestans [115], another vector of T. cruzi. Yet, T. infestans midgut TiCatD is strongly induced after feeding whereas TiCatD2 is upregulated only 10 to 20 days after meal, suggesting that the former might play a role in processes related to early digestion [116]. The midgut transcriptome of $R$. prolixus shows that transcripts from digestive enzymes are significantly well expressed, with a predominance of cysteine and aspartic proteases [117].

More recently, triatomine cathepsin D has also been proposed to be involved in vitellogenesis. Dipetalogaster maxima cathepsin D (DmCatD) is expressed in the fat body and ovarian tissues during the reproductive cycle. As for other peptidases, DmCatD also degrades Vt. Early activation of DmCatD seems to be a relevant physiological mechanism in yolk protein degradation during follicular atresia to either increase female lifetime or sustain younger oocytes until improvement of nutritional conditions [118].

Triapsin is the best serine protease characterized in triatomines. This trypsin-like SP is expressed in the D2 pair of $T$. infestans salivary glands as an inactive precursor and activated during salivation stimulated by biting. Triapsin shows high specificity towards arginine at the P1 site. This protease may be involved in hydrolysis of the superfamily of Proteinase Activated G protein-coupled Receptors (PAR), which regulates growth, development, inflammation, and responses to injury. Triapsin is unlikely to be involved in digestion since this phenomenon in Hemiptera seems to depend exclusively on the action of cysteine and aspartic proteases [18]. However, it is imperative to perform experiments to test the involvement of this peptidase on the physiology of triatomines and other insect vectors of illnesses.
Our group has used next-generation sequencing and mass spectrometry-based protein identification to study the transcriptome and proteome of $R$. neglectus salivary glands (sialome) [25]. The results have revealed abundant transcripts of putative secreted trypsin-like peptidases, although only one SP was detected in the proteome, suggesting physiological conditions may influence secretion [25]. Sequence alignments disclosed the presence of domains present in proteins that act in haemostasis and immunity such as the CUB domain [119] and the cysteine-stabilized structures for molecular recognition (CLIP, LDLa and SUSHI domains). Five SP sequences from $R$. neglectus sialotranscriptome [25] match to SPs sequences from $T$. infestans $[28,120], T$. braziliensis [29], P. megistus [30] and R. prolixus [117]. Although physiological roles of SPs are unknown, their presence in the sialotranscriptome of different triatomine species is indicative of the importance of these proteases in haematophagy.

Two metalloproteases are expressed in the haemolymph of $R$. prolixus infected with Enterobacter cloacae [121] or Trypanosoma rangeli [122]. The source of these proteases is the fat body and their release into the haemolymph upon infection suggests these enzymes may be involved in $R$. prolixus defence mechanisms. In T. matogrossensis saliva [123] and $R$. prolixus oddities [117], sequences related to the astacin family of metalloproteases have been reported. In the sialome of $R$. neglectus, one coding sequence related to the zinc-dependent metalloproteases from the astacin-like metalloproteases as well as other two related to the adamalysin/reprolysin family, which includes ADAMTS (A Disintegrin and Metalloproteinase with Thrombospondin motifs), have also been reported. Both are members of the metzincins metalloproteases superfamily [25]. Astacin family members can hydrolyse 


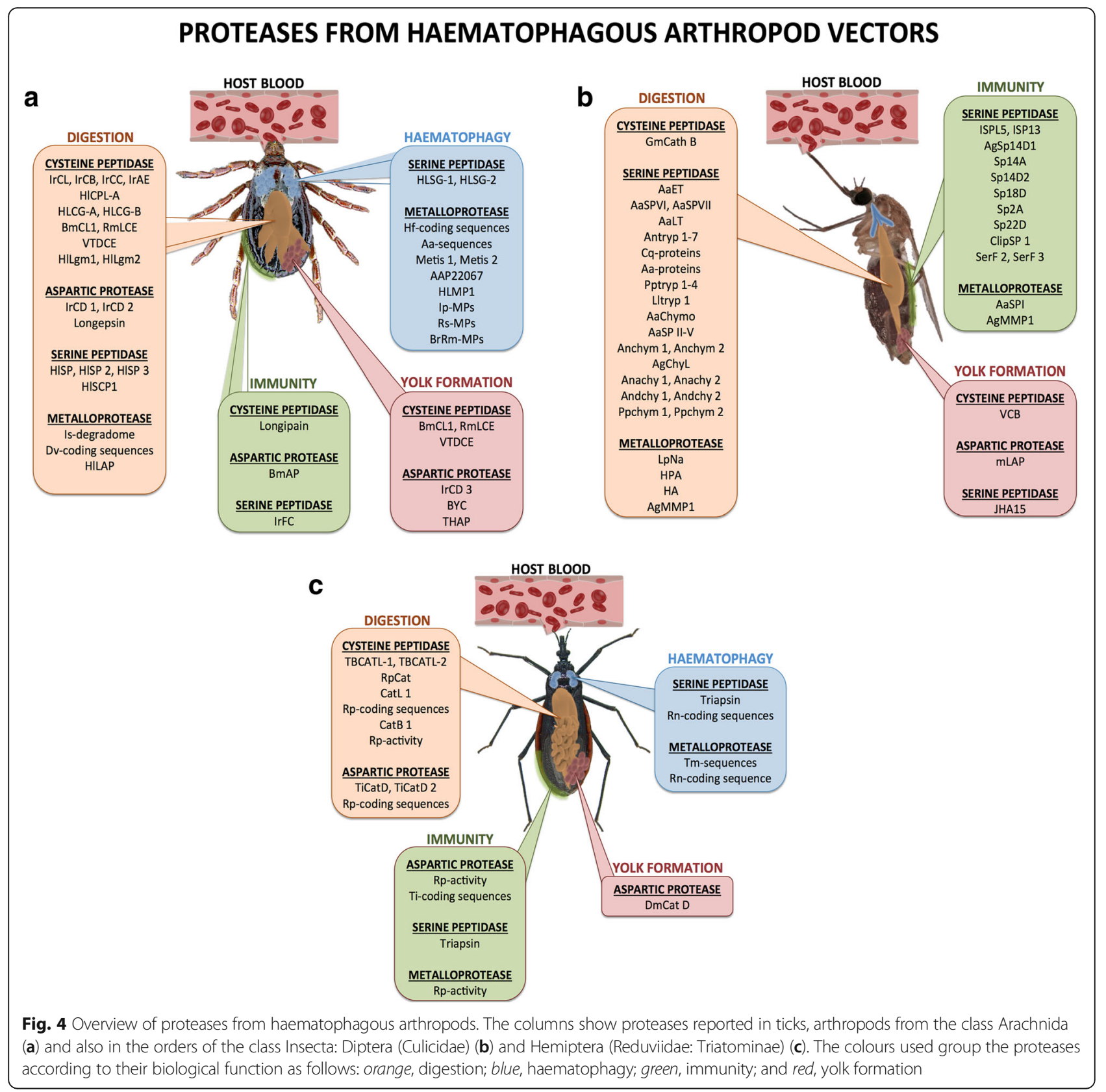

fibrinogen and fibronectin [124-126], leading to local haemorrhage [127], whereas disintegrins bind to platelets acting as potent inhibitors of platelet aggregation [128-130]. These proteases may have key functions in the maintenance of blood flow at the bite site. In summary, in triatomines vectors, as observed in ticks, protease activities involved in digestion belong to cysteine and aspartic families (Table 4 and Fig. 4), whereas serine- and metallo- proteases seem to participate in some aspects of haematophagy and immunity.

\section{In mosquitoes}

Vitellogenic cathepsin B (VCB) from Aedes aegypti mosquito is specifically expressed by fat body during vitellogenesis in response to repast, internalized by developing oocytes, and deposited in the yolk bodies for the onset of embryogenesis. VCB hydrolyses $\mathrm{Vg}$ at acidic $\mathrm{pH}$, and may be involved in the embryonic degradation of yolk proteins [131].

In female Ae. aegypti two different groups of gut trypsins show different levels of expression after a blood meal. The first one is the early trypsin group, whose 
Table 4 Proteases from triatomines

\begin{tabular}{|c|c|c|c|c|c|c|}
\hline Protease & Species & $\begin{array}{l}\text { Synthetic/Natural } \\
\text { substrate }\end{array}$ & Inhibitor & Localization & Role & Reference \\
\hline \multicolumn{7}{|l|}{ Cysteine } \\
\hline \multicolumn{7}{|l|}{ Cathepsin L } \\
\hline TBCATL-1; TBCATL-2 & Triatoma brasiliensis & Gelatin & $\mathrm{E}-64 ; \mathrm{CA}-074$ & Gut & Digestion & [109] \\
\hline RpCat & Rhodnius prolixus & - & - & Gut & Digestion & [110] \\
\hline CatL1 & Triatoma infestans & - & - & - & Digestion & [111] \\
\hline Rp-coding sequences & R. prolixus & - & - & Gut & Digestion & {$[117]$} \\
\hline \multicolumn{7}{|l|}{ Cathepsin B } \\
\hline CatB1 & T. infestans & Z- Phe-Arg-pNA & E-64; CA-074 & Gut & Digestion & [111] \\
\hline Rp-activity & R. prolixus & $\begin{array}{l}\text { N-Benzoyl-DL-Arg- } \beta \text { - } \\
\text { Napthylamide }\end{array}$ & - & Gut & Digestion & [113] \\
\hline \multicolumn{7}{|l|}{ Aspartic; Cathepsin D } \\
\hline Rp-activity & R. prolixus & $\mathrm{Hb}$ & Pepstatin A & Gut & Immunity & [114] \\
\hline Ti-coding sequences & T. infestans & - & - & Gut & Immunity & [115] \\
\hline TiCatD; TiCatD2 & T. infestans & $\begin{array}{l}\text { MOCAc-GKPILFwFRLK } \\
\text { (Dnp)-D-R-NH2 }\end{array}$ & Pepstatin A & Gut & Digestion & [116] \\
\hline Rp-coding sequences & R. prolixus & - & - & Gut & Digestion & [117] \\
\hline DmCatD & Dipetalogaster maxima & - & - & Fat body & Yolk formation & [118] \\
\hline \multicolumn{7}{|l|}{ Serine; Trypsin-like } \\
\hline Triapsin & T. infestans & $\begin{array}{l}\text { pNA; H-D-lle-Pro- } \\
\text { Arg-pNA }\end{array}$ & $\begin{array}{l}\text { APMSF; SBTI; } \\
\text { Antipain }\end{array}$ & Salivary glands & Haematophagy & [18] \\
\hline Rn-coding sequences & Rhodnius neglectus & - & - & Salivary glands & Haematophagy & {$[25]$} \\
\hline \multicolumn{7}{|l|}{ Metallo } \\
\hline Rp-activity & R. prolixus & Gelatin & $\begin{array}{l}1-10 \\
\text { Phenanthroline }\end{array}$ & Fat body; haemolymph & Immunity & {$[121,122]$} \\
\hline \multicolumn{7}{|l|}{ Astacin } \\
\hline Tm-sequences & Triatoma matogrossensis & - & - & Salivary glands & Haematophagy & [123] \\
\hline Rp-sequences & R. prolixus & - & - & Oddities & - & \\
\hline Rn-coding sequence & R. neglectus & - & - & Salivary glands & Haematophagy & [25] \\
\hline \multicolumn{7}{|l|}{ Reprolysin } \\
\hline Rn-coding sequence & R. neglectus & - & - & Salivary glands & Haematophagy & {$[25]$} \\
\hline
\end{tabular}

transcription occurs in the midgut of newly emerged adult before feeding and is under the control of $\mathrm{JH}$ [132], being translated at detectable levels after bloodfeeding [133, 134]. Early trypsins, secreted either through stretching of the midgut or osmotic effect, would be required for the transcription of the second group, the late trypsins. It is possible that released amino acids are also involved in this process $[135,136]$. Expression of late trypsins requires complete synthesis of new mRNAs after feeding, produced in large amounts 8$10 \mathrm{~h}$ after a blood meal, suggesting it may have a major role in the digestive process [133]. These two phases would allow the mosquitoes to assess the quality of the meal before committing to the synthesis of late trypsins, since large amount of these proteases in the absence of blood might be harmful for the mosquitoes [135].
Within this context, three trypsins of Ae. aegypti [Aedes Early Trypsin (AaET), AaSPVI and AaSPVII] had their enzymatic activities compared among them and with bovine trypsin (BvT). The specific activities of AaET and BvT are comparable, and 5-10 times higher than those of AaSPVI and AaSPVII late trypsins. In addition, AaSPVI is 3-4 times more active on $\mathrm{Hb}$ than AaET and AaSPVII [137]. AaSPVI RNAi knockdown, but not that of AaSPVII, triggers a significant decrease in the late phase trypsin-like activity. In contrast, injections of AaSPVI and AaSPVII dsRNAs decrease both degradation of endogenous serum albumin in vivo and egg production. Taken together, these data indicate that AaSPVI and AaSPVII contribute to blood digestion and oocyte maturation [138]. Ae. aegypti late trypsin (AaLT), that lacks trypsin-like activity, and AaSPI are classified as collagenase-like SP and might be 
related to mosquito defence against complement present in the host blood [139].

A gene cluster of gut trypsin-like SPs, Antryp 1-7, has been identified in Anopheles gambiae [140-142]. Antryp 1 and 2 present selective proteolytic activity against blood components; Antrypl mediates degradation of both $\mathrm{Hb}$ and serum albumin, whereas Antryp2 seems to be mainly active on $\mathrm{Hb}$. While transcription of Antryp 1 and 2 is induced after a blood meal, Antryp 3-7 are constitutively transcribed in females and their levels are down-regulated after blood-feeding. These observations suggest that Antryp 3-7 are involved in initiating the events leading to the expression of other SPs directly associated with digestion [140-142]. Trypsin-like SPs activities have also been observed in An. aquasalis females [143]. In the Aedes [144] and Anopheles [145] these proteases share an acidic isoelectric point, but differ in size.

Regarding Culex quinquefasciatus, a proteomic approach associated with zymographic analysis has identified eight trypsin-like proteases in the midgut of females fed on sugar [146]. These enzymes are specific to $C$. quinquefasciatus when compared to the culicids genomes sequenced so far. Moreover, these proteases exhibit singularities at the protein sequence level such as the presence of different amino acids at the autocatalytic motif and substrate binding regions [146].

A female specific Ae. aegypti chymotrypsin-like SP gene (JHA15 or AaJA15) is required in the yolk for embryo development and is regulated in a dose-dependent manner by JH [147]. Five other Ae. aegypti chymotrypsin-like SP genes (AaChymo, AaSP II-V) have been cloned and sequenced [139]. Northern and Western blots analyses have shown that AaChymo mRNA is abundant in the adult female midgut and its expression is induced after a blood meal [148]. On the other hand, midgut AaSP II-V are equally expressed before and after a blood meal [139]. An explanation for this observation awaits further investigations. In Ae. albopictus females two different trypsinlike SPs and one chymotrypsin have been identified by means of two-dimensional electrophoresis of midgut proteins [149].

A study of two midgut An. gambiae chymotrypsins (Anchym1 and Anchym2) has revealed the presence of $\mathrm{N}$-terminus preceded by an arginine, indicating zymogen activation by tryptic cleavage. It has been suggested that these chymotrypsins are members of a digestive cascade initiated upon tryptic activation [150]. In the An. gambiae midgut the chymotrypsin (AgChyL) is restricted to the adult female stage and contains a Thr residue at the position 182, a feature that could determine its narrow specificity range [151]. In other two species of Anopheles, An. aquasalis (Anachy1 and Anachy2) and An. darlingi (Andchy1 and Andchy2), two closely related chymotrypsins have also been reported. Anachy1 and Anachy 2 mRNAs seem to be detectable only in adult females, approximately $24 \mathrm{~h}$ after the blood meal [152].

An intriguing possibility is that SPs levels in haematophagous vectors may be associated with infections. Eight immune related SPs have been described in An. gambiae: ISPL5, ISP13 [153, 154], AgSp14D1 [155], Sp14A, Sp14D2, Sp18D, Sp2A [156], and Sp22D [156, 157]. These SPs, except for Sp18D and Sp2A, probably participate in the anti-bacterial and anti-Plasmodium defence mechanisms [153-155]. Furthermore, AgSp14D1 catalytic domain has similar sequence identities to kallikreins and coagulation factors, members that are involved in immune and wound responses [155]. Sp14A, Sp14D1, and Sp14D2 present an amino-terminal clip domain, characteristic of secreted proteases that activate prophenoloxidases, regulate melanotic parasite encapsulation and antimicrobial peptide synthesis [155]. Regarding Sp22D mRNA, it is expressed constitutively in three immune related cell types: adult hemocytes, fat body, and midgut epithelial cells. The authors suggest that $\mathrm{Sp} 22 \mathrm{D}$ is secreted into the hemolymph where it may interact with pathogen surfaces and initiate an immune response as rapid as pathogen detection [157]. Sp2A and Sp18D functions remain to be characterized, although Sp18D present the clip domain and $\mathrm{Sp} 2 \mathrm{~A}$ is similar to vertebrate and invertebrate blood coagulation factors [155]. In An. dirus, the main vector of malaria in Southeast Asia, the SP cDNAs for ClipSP1, SerF2, and SerF3 have been analyzed upon $P$. falciparum infection. Only SerF3 seems to be upregulated in infected $A n$. dirus, and might also play a role in the mosquito immunity [158].

Metalloproteases have also been reported in mosquitoes. Late metalloprotease trypsin, leucineaminopeptidase (LpNa), carboxypeptidase A (HPA) and carboxypeptidase B (HA) of the midgut of Ae. aegypti females present enzymatic activities stimulated $20-24 \mathrm{~h}$ after a blood or protein, but not free amino acids meal. There is a positive correlation between metalloprotease activity and protein concentration in the meal [159]. AgMMP1, a matrix metalloprotease (MMP) from An. gambiae, is expressed as a transmembrane/membrane protein (MT-MMP1) in epithelial tissues and as a secreted (S-MMP1) isoform in hemocytes. MT-MMP1 transcript levels show a remarkable response to blood meal digestion and to midgut invasion by Plasmodium ookinetes [160]. Since tissue invaded by pathogens has often been associated with increased MMP activity, this study suggests MMPs may have an impact in vector competence determination [161, 162].

The mRNA of lysosomal aspartic protease (mLAP) of Ae. aegypti females is expressed in fat body during vitellogenesis and is upregulated between 6 and $12 \mathrm{~h}$ after blood meal, with high levels at $24 \mathrm{~h}$ and then gradually 
Table 5 Proteases from dipterans

\begin{tabular}{|c|c|c|c|c|c|c|}
\hline Protease & Species & Synthetic/Natural substrate & Inhibitor & Localization & Role & Reference \\
\hline \multicolumn{7}{|l|}{ Cystein } \\
\hline \multicolumn{7}{|l|}{ Cathepsin B } \\
\hline VCB & Aedes aegypti & Z-Arg-Arg-pNA & E-64; Chymostatin & Fat body & Yolk formation & [131] \\
\hline GmCath B & Glossina morsitans & $\mathrm{Hb}$; Serum albumin & - & Gut & Digestion & {$[170]$} \\
\hline \multicolumn{7}{|l|}{ Cathepsin D } \\
\hline mLAP & Ae. aegypti & - & - & Fat body & Yolk formation & [163] \\
\hline \multicolumn{7}{|l|}{ Serine; Trypsin-like } \\
\hline AaET; AaSPVI; AaSPVII & Ae. aegypti & BApNA & - & Gut & $\begin{array}{l}\text { Digestion; yolk } \\
\text { formation }\end{array}$ & {$[137,138]$} \\
\hline AaLT & Ae. aegypti & - & - & Gut & $\begin{array}{l}\text { Digestion; yolk } \\
\text { formation }\end{array}$ & {$[136,137]$} \\
\hline Antryp-7 & Anopheles gambiae & - & PMSF & Gut & Digestion & [140-142] \\
\hline Cq-proteins & Culex quinquefasciatus & - & - & Gut & Digestion & [146] \\
\hline Aa-proteins & Aedes albopictus & - & - & Gut & Digestion & [149] \\
\hline ISPL5; ISP13 & An. gambiae & - & - & Gut & Immunity & {$[153,154]$} \\
\hline AgSP14D1 & An. gambiae & - & - & Gut & Immunity & [155] \\
\hline SP14A; SP14D2; SP18D; SP2A & An. gambiae & - & - & Haemolymph & Immunity & [156] \\
\hline SP22D & An. gambiae & - & - & Haemolymph & Immunity & [157] \\
\hline ClipSP 1; SerF 2; SerF 3 & Anopheles dirus & - & - & Fat body & Immunity & [158] \\
\hline Pptryp 1-4 & Phlebotomus papatasi & $\begin{array}{l}\text { BapNa; N-Suc-Ala-Ala- } \\
\text { Pro-Phe-pNA }\end{array}$ & $\begin{array}{l}\text { 2-nitro-4- } \\
\text { carboxyphenyl-N, } \\
\text { N-diphenylcarbamate }\end{array}$ & Gut & Digestion & [164] \\
\hline Lltryp 1; LItryp 2 & Lutzomyia longipalpis & - & TPCK; PMSF; TLCK & Gut & Digestion & {$[165,166]$} \\
\hline \multicolumn{7}{|l|}{ Chymotrypsin-like } \\
\hline $\mathrm{JHA} 15$ & Ae. aegypti & $\begin{array}{l}\text { N-Suc-Ala-Ala-Pro- } \\
\text { Phe-pNA }\end{array}$ & Chymostatin & Gut & Development & [147] \\
\hline AaChymo & Ae. aegypti & - & - & Gut & Digestion & [139] \\
\hline AaSP II-V & Ae. aegypti & - & - & Gut & Digestion & [139] \\
\hline Aa-protein & Ae. albopictus & - & - & Gut & Digestion & [149] \\
\hline Anchym 1; Anchym 2 & An. gambiae & - & - & Gut & Digestion & [150] \\
\hline AgChyL & An. gambiae & $\begin{array}{l}\text { N-Suc-Ala-Ala-Pro- } \\
\text { Phe-pNA }\end{array}$ & - & Gut & Digestion & {$[151]$} \\
\hline Anachy1; Anachy2 & Anopheles aquasalis & Z-Phe-Arg-AMC & PMSF; TLCK & Gut & Digestion & {$[152]$} \\
\hline Andchy1; Andchy2 & Anopheles darlingi & - & - & Gut & Digestion & [152] \\
\hline Ppchym 1; Ppchym 2 & P. papatasi & $\begin{array}{l}\text { BapNa; N-Suc-Ala- } \\
\text { Ala-Pro-Phe-pNA }\end{array}$ & $\begin{array}{l}\text { 2-nitro-4- } \\
\text { carboxyphenyl- } \mathrm{N}, \\
\mathrm{N} \text {-diphenylcarbamate }\end{array}$ & Gut & Digestion & [164] \\
\hline \multicolumn{7}{|l|}{ Colagenase-like } \\
\hline AaSPI & Ae. aegypti & - & - & Gut & Immunity & [139] \\
\hline \multicolumn{7}{|c|}{ Metallo; Leucine-aminopeptidases } \\
\hline LpNa & Ae. aegypti & Leu-pNa & $\begin{array}{l}\text { Leuhistin; Amastatin; } \\
\text { Bestatin }\end{array}$ & Gut & Digestion & [159] \\
\hline \multicolumn{7}{|l|}{ Carboxypeptidase A and B } \\
\hline $\mathrm{HPA} ; \mathrm{HA}$ & Ae. aegypti & $\begin{array}{l}\text { Hippuril-Phe; } \\
\text { Hippuril-Arg }\end{array}$ & 1-10 Phenanthroline & Gut & Digestion & [159] \\
\hline \multicolumn{7}{|l|}{ MMP } \\
\hline AgMMP 1 & An. gambiae & Casein & - & Gut & $\begin{array}{l}\text { Digestion; } \\
\text { immunity }\end{array}$ & {$[160]$} \\
\hline
\end{tabular}


declining. It has been suggested a negative translational regulation of mLAP expression by 20-HE [163].

In summary, the vast majority of mosquito peptidases are serine proteases involved in digestion (Table 5 and Fig. 4), and evidences indicate that they probably participate in other processes, including immunity and development, suggesting they are multitasking enzymes. Interestingly, a member of the metalloprotease class is also involved in digestion. Additionally, although products coding for serine proteases from salivary gland transcriptome have been reported in some mosquito species, the question of whether they have a function in saliva remains to be investigated.

\section{In other dipterans}

Four trypsin-like (Pptryp1-Pptryp4) and two chymotrypsinlike (Ppchym1 and Ppchym2) cDNAs from Phlebotomus papatasi midgut have been studied. Ppchym1 and Ppchym2 expression profiles are similar to Ae. aegypti early and late trypsins, suggesting that a two-phase digestive mechanism also occurs in sand flies [164]. In Lutzomyia longipalpis two trypsin-like SP cDNAs, Lltryp1 and Lltryp2, have also been described [165]. While Lltryp1 is expressed in females after a blood meal, Lltryp2 is detected in both sexes regardless of feeding. L. longipalpis infection by Leishmania major promastigotes has not modified the expression levels of Lltryp1 and Lltryp2. It is plausible that different results may be obtained when infections are performed with Leishmania chagasi amastigotes [166]. In contrast, a correlation has been reported between Leishmania spp. infections and reduced trypsin-like SP activity in P. papatasi. The presence of specific inhibitors of trypsin in the blood meal prevents the early killing of $L$. major and Leishmania donovani in the midgut of this insect species, implying that the proteolytic activity in the sand fly midgut modulates vector susceptibility to infections [167-169]. Finally, a cathepsin B (GmcathB) from tsetse Glossina morsitans morsitans is induced after blood meal and can degrade bovine $\mathrm{Hb}$ and serum albumin in a wide $\mathrm{pH}$ range [170].

\section{Conclusions}

In this review, we discussed the role of some proteases involved in processes related to the blood-feeding habit of arthropods: blood sucking, digestion, yolk formation, immunity and in the transmission and survival of pathogens. The diversity and expansion of proteases families assigned to these processes in the insects and ticks presented here reinforce the hypothesis that haematophagy evolved independently several times in haematophagous organisms, including within Insecta $[15,171]$. It is possible that to adapt to blood-feeding habit, the set of proteins available in an ancestral non-haematophagous lineage have faced the challenge of developing new biological activities, resulting in the generation of the essential nutrients and detoxification of the adverse molecules [172].

The combination of arthropod cysteine/aspartic protease network for protein digestion may have evolved early in metazoan, predating the transition to serine proteases based digestion found in insects $[85,173,174]$. The remarkable exception for this picture occurs in triatomine bugs, a feature consistent with its evolutionary path from hemipteran ancestors feeding on sap and seeds, which may have re-routed the extracellular digestion from trypsins to cathepsins to avoid the trypsin inhibitors found on seeds [4]. Therefore, two evolutionarily distinct haematophagous vectors, ticks and triatomines, utilize this combination of cysteine and aspartic proteases to perform most of the digestive function [11]. Notably, the evolutionary path of these vectors indicates that their conserved bulk of digestive proteases are related by convergent evolution [172].

We have noticed that authors have given different names for proteases belonging to the same clan or isoforms even in a single organism. This issue calls for a unified nomenclature to avoid misunderstanding and ambiguities. Thus, we suggest that a careful sequence analysis be done when describing a new gene to name it according to the clan (or clan prototype) name and in the case of already studied proteases, rename them. MEROPS database (merops.sanger.ac.uk) is very useful to define accurate systematic nomenclature, since it allows search for organism peptidase, family, clans, substrates, inhibitors and other resources.

Considering the central functions that proteases from haematophagous arthropod vectors have, a question that arose is whether proteases could be employed as potential targets for the development of alternative strategies for arthropod vector control, for instance, in the emerging investigation on arthropod protease inhibitors [175]. Another question would be if these molecules can stimulate immune mechanisms in the host that could block the transmission of microorganisms by these vectors. Resolving this issue would require the isolation of the best candidates and to accomplish extensive investigations aiming to determine the molecular interactions and mechanisms involved in the functions of proteases.

\section{Additional file}

\footnotetext{
Additional file 1: Overview of multiple sequence alignment of ten predicted Cathepsin L from $R$. (B.) microplus. The alignments were performed by multiple sequence comparison using Clustal Omega (http://www.ebi.ac.uk/ Tools/msa/clustalo/), and manually edited using Aline (http://bondxray.org/ software/aline.html). Black, fully conserved residues. Gray, not conserved residues. Blue, catalytic residues. (BMP 2207 kb)
} 


\section{Abbreviations}

20-HE: 20-hydroxyecdysone; CUB: Complement C1r/C1s, Uegf, Bmp1 domain; DREDD: Caspase-8 like; EDNH: Egg development neurosecretory hormone; Hb: Haemoglobin; IMD: Immunodeficiency pathway; JH: Juvenile hormone; LDLa: Low-density lipoprotein receptor domain class A; PAR: Proteinaseactivated G protein coupled receptors; PO: Phenoloxidase; SPs: Serine proteases; SUSHI: Domain abundant in complement control proteins; Vg: Vitellogenin; Vt: Vitellin

\section{Acknowledgements}

We are grateful to the Vice-Presidency for Research and Graduate Studies of the University of Brasília.

\section{Funding}

This work was supported by MCTI/CNPq/FNDCT/PRO-CENTRO-OESTE (407730/ 2013-3 and 407855/2013-0), CAPES/Incentivo a Pesquisa em Parasitologia Básica (23038.005298/2011-83), FAPDF (193.001.076/2015, 193.001.053/2015 and 193.000.822/2015), INCT-CNPq-FAPERG (465771/2014-9), CNPq, Finep and UnB.

\section{Availability of data and materials}

Not applicable.

\section{Authors' contributions}

PBS, CNA, FNM, YRP, SC, IMDB: conceived the study, and wrote the manuscript. JMS: participated in design, coordination and wrote the manuscript. All authors read and approved the final manuscript.

\section{Competing interests}

The authors declare that they have no competing interests.

\section{Consent for publication}

Not applicable.

\section{Ethics approval and consent to participate}

Not applicable.

\section{Author details}

'Laboratório de Interação Patógeno-Hospedeiro, Departamento de Biologia Celular, Instituto de Ciências Biológicas, Universidade de Brasília, Campus Universitário Darcy Ribeiro, Asa Norte, 70910-900 Brasília, DF, Brazil. ${ }^{2}$ Faculdade de Ceilândia, Universidade de Brasília, Centro Metropolitano, Conjunto A, Lote 01, 72220-275 Brasília, DF, Brazil. Programa Pós-Graduação em Ciências Médicas, Faculdade de Medicina, Universidade de Brasília, Campus Universitário Darcy Ribeiro, Asa Norte, 70910-900 Brasília, DF, Brazil. ${ }^{4}$ Laboratório de Bioquímica e Química de Proteínas, Departamento de Biologia Celular, Instituto de Ciências Biológicas, Universidade de Brasília, Campus Universitário Darcy Ribeiro, Asa Norte, 70910-900 Brasília, DF, Brazil.

Received: 17 June 2016 Accepted: 27 January 2017

\section{Published online: 13 February 2017}

\section{References}

1. Mehlhorn H. Arthropods as vectors of emerging diseases, vol. 3. Germany: Springer International Publishing AG; 2012.

2. World Health Organization. Vector-borne diseases. 2016. http://www.who. int/mediacentre/factsheets/fs387/en/. Accessed 15 Sep 2016.

3. Ribeiro G, Gurgel-Gonçalves R, Reis RB, Santos CG, Amorim A, Andrade SG, et al. Frequent house invasion of Trypanosoma cruzi-infected triatomines in a suburban area of Brazil. PLoS Negl Trop Dis. 2015;9(4):e0003678.

4. Lehane. The biology of blood-sucking in insects. 2nd ed. New York: Cambridge University Press; 2005.

5. Ribeiro JM. Role of saliva in blood-feeding by arthropods. Annu Rev Entomol. 1987:32:463-78

6. de Araújo CN, Bussacos AC, Sousa AO, Hecht MM, Teixeira AR. Interactome: smart hematophagous triatomine salivary gland molecules counteract human hemostasis during meal acquisition. J Proteomics. 2012;75(13): 3829-41.

7. Fontaine A, Diouf I, Bakkali N, Missé D, Pagès F, Fusai T, et al. Implication of haematophagous arthropod salivary proteins in host-vector interactions. Parasit Vectors. 2011;4:187.
8. Kotál J, Langhansová H, Lieskovská J, Andersen JF, Francischetti IM, Chavakis T, et al. Modulation of host immunity by tick saliva. J Proteomics. 2015;128:58-68.

9. Chmelař J, Kotál J, Karim S, Kopacek P, Francischetti IM, Pedra JH, et al. Sialomes and mialomes: a systems-biology view of tick tissues and tick-host interactions. Trends Parasitol. 2016;32(3):242-54.

10. Ribeiro JM. Vector salivation and parasite transmission. Mem Inst Oswaldo Cruz. 1987;82(3):1-3

11. Sojka D, Franta Z, Horn M, Caffrey CR, Mareš M, Kopáček P. New insights into the machinery of blood digestion by ticks. Trends Parasitol. 2013;29(6): 276-85.

12. Rawlings ND, Barrett AJ, Finn R. Twenty years of the MEROPS database of proteolytic enzymes, their substrates and inhibitors. Nucleic Acids Res. 2016; 44:D343-50.

13. Rawlings ND, Waller M, Barrett AJ, Bateman A. MEROPS: the database of proteolytic enzymes, their substrates and inhibitors. Nucleic Acids Res. 2014;42:D503-9.

14. Khan AR, James MN. Molecular mechanisms for the conversion of zymogens to active proteolytic enzymes. Protein Sci. 1998;7(4):815-36.

15. Ribeiro JMC, Arca B. From Sialomes to the sialoverse: an insight into salivary potion of blood-feeding insects. Adv Insect Physiol. 2009;37:59-118.

16. Rivera J, Lozano ML, Navarro-Núñez L, Vicente V. Platelet receptors and signaling in the dynamics of thrombus formation. Haematologica. 2009; 94(5):700-11.

17. Francischetti IM, Sa-Nunes A, Mans BJ, Santos IM, Ribeiro JM. The role of saliva in tick feeding. Front Biosci. 2009;14:2051-88.

18. Amino R, Tanaka AS, Schenkman S. Triapsin, an unusual activatable serine protease from the saliva of the hematophagous vector of Chagas' disease Triatoma infestans (Hemiptera: Reduviidae). Insect Biochem Mol Biol. 2001 31(4-5):465-72.

19. Francischetti IM, Mather TN, Ribeiro JM. Cloning of a salivary gland metalloprotease and characterization of gelatinase and fibrin(ogen)lytic activities in the saliva of the Lyme disease tick vector Ixodes scapularis. Biochem Biophys Res Commun. 2003;305(4):869-75.

20. Faudry E, Lozzi SP, Santana JM, D'Souza-Ault M, Kieffer S, Felix CR, et al. Triatoma infestans apyrases belong to the $5^{\prime}$-nucleotidase family. J Biol Chem. 2004:279(19):19607-13.

21. Kazimírová M, Štibrániová I. Tick salivary compounds: their role in modulation of host defences and pathogen transmission. Front Cell Infect Microbiol. 2013;3:43.

22. Chmelar J, Calvo E, Pedra JH, Francischetti IM, Kotsyfakis M. Tick salivary secretion as a source of antihemostatics. J Proteomics. 2012;75(13):3842-54.

23. Ribeiro JMC, Assumpção TC, Francischetti IMB. An insight into the sialomes of bloodsucking Heteroptera. Psyche. 2012;2012(470436):16.

24. Calvo E, Mizurini DM, Sá-Nunes A, Ribeiro JM, Andersen JF, Mans BJ, et al. Alboserpin, a factor Xa inhibitor from the mosquito vector of yellow fever, binds heparin and membrane phospholipids and exhibits antithrombotic activity. J Biol Chem. 2011;286(32):27998-8010.

25. Santiago PB, Assumpção TC, Araújo CN, Bastos IM, Neves D, Silva IG, et al. A deep insight into the sialome of Rhodnius neglectus, a vector of Chagas disease. PLoS Negl Trop Dis. 2016;10(4):e0004581.

26. Assumpção TC, Charneau S, Santiago PB, Francischetti IM, Meng Z, Araújo $\mathrm{CN}$, et al. Insight into the salivary transcriptome and proteome of Dipetalogaster maxima. J Proteome Res. 2011;10(2):669-79.

27. Ribeiro JM, Mans BJ, Arcà B. An insight into the sialome of blood-feeding Nematocera. Insect Biochem Mol Biol. 2010:40(11):767-84.

28. Assumpção TC, Francischetti IM, Andersen JF, Schwarz A, Santana JM, Ribeiro JM. An insight into the sialome of the blood-sucking bug Triatoma infestans, a vector of Chagas' disease. Insect Biochem Mol Biol. 2008;38(2): 213-32.

29. Santos A, Ribeiro JM, Lehane MJ, Gontijo NF, Veloso AB, Sant'Anna MR, et al. The sialotranscriptome of the blood-sucking bug Triatoma brasiliensis (Hemiptera, Triatominae). Insect Biochem Mol Biol. 2007;37(7):702-12.

30. Ribeiro JM, Schwarz A, Francischetti IM. A deep insight into the sialotranscriptome of the Chagas disease vector, Panstrongylus megistus (Hemiptera: Heteroptera). J Med Entomol. 2015;52(3):351-8.

31. Karim S, Singh P, Ribeiro JM. A deep insight into the sialotranscriptome of the gulf coast tick, Amblyomma maculatum. PLoS One. 2011;6(12), e28525.

32. de Castro $\mathrm{MH}$, de Klerk D, Pienaar R, Latif AA, Rees DJ, Mans BJ. De novo assembly and annotation of the salivary gland transcriptome of Rhipicephalus appendiculatus male and female ticks during blood feeding. Ticks Tick Borne Dis. 2016;7(4):536-48. 
33. Yu X, Gong H, Zhou Y, Zhang H, Cao J, Zhou J. Differential sialotranscriptomes of unfed and fed Rhipicephalus haemaphysaloides, with particular regard to differentially expressed genes of cysteine proteases. Parasit Vectors. 2015:8:597.

34. Garcia GR, Gardinassi LG, Ribeiro JM, Anatriello E, Ferreira BR, Moreira HN, et al. The sialotranscriptome of Amblyomma triste, Amblyomma parvum and Amblyomma cajennense ticks, uncovered by 454-based RNA-seq. Parasit Vectors. 2014;7:430.

35. Calvo E, Sanchez-Vargas I, Favreau AJ, Barbian KD, Pham VM, Olson KE, et al. An insight into the sialotranscriptome of the West Nile mosquito vector, Culex tarsalis. BMC Genomics. 2010;11:51.

36. Calvo E, Pham VM, Marinotti O, Andersen JF, Ribeiro JM. The salivary gland transcriptome of the neotropical malaria vector Anopheles darlingi reveals accelerated evolution of genes relevant to hematophagy. BMC Genomics. 2009;10:57.

37. Guo X, Booth CJ, Paley MA, Wang X, DePonte K, Fikrig E, et al. Inhibition of neutrophil function by two tick salivary proteins. Infect Immun. 2009;77(6): 2320-9

38. Sojka D, Pytelková J, Perner J, Horn M, Konvičková J, Schrenková J, et al. Multienzyme degradation of host serum albumin in ticks. Ticks Tick Borne Dis. 2016;7(4):604-13.

39. Lehane M, Billingsley P. Biology of the insect midgut. 1st ed. Dordrecht: Springer Netherlands; 1996.

40. Dow JAT. Advances in insect physiology. Ames: Elsevier; 1987. p. 19

41. Sonenshine DE, Roe RM. Biology of ticks. 2nd ed. USA: Oxford University Press; 2013.

42. Lara FA, Lins $U$, Bechara GH, Oliveira PL. Tracing heme in a living cell: hemoglobin degradation and heme traffic in digest cells of the cattle tick Boophilus microplus. J Exp Biol. 2005;208(Pt16):3093-101.

43. Graça-Souza AV, Maya-Monteiro C, Paiva-Silva GO, Braz GR, Paes MC, Sorgine $\mathrm{MH}$, et al. Adaptations against heme toxicity in blood-feeding arthropods. Insect Biochem Mol Biol. 2006:36(4):322-35.

44. Horn M, Nussbaumerová M, Sanda M, Kovárová Z, Srba J, Franta Z, et al. Hemoglobin digestion in blood-feeding ticks: mapping a multipeptidase pathway by functional proteomics. Chem Biol. 2009;16(10):1053-63.

45. Sojka D, Francischetti IM, Calvo E, Kotsyfakis M. Cysteine proteases from bloodfeeding arthropod ectoparasites. Adv Exp Med Biol. 2011;712:177-91.

46. Raikhel AS, Dhadialla TS. Accumulation of yolk proteins in insect oocytes. Annu Rev Entomol. 1992;37:217-51.

47. Attardo GM, Hansen IA, Raikhel AS. Nutritional regulation of vitellogenesis in mosquitoes: implications for anautogeny. Insect Biochem Mol Biol. 2005 35(7):661-75.

48. Uchida K, Ohmori D, Yamakura F, Suzuki K. Changes in free amino acid concentration in the hemolymph of the female Culex pipiens pallens (Diptera: Culicidae), after a blood meal. J Med Entomol. 1990;27(3):302-8.

49. Tsakas $S$, Marmaras $V$. Insect immunity and its signaling: an overview. Invert Surviv J. 2010:7:228-38

50. Hajdušek O, Síma R, Ayllón N, Jalovecká M, Perner J, de la Fuente J, et al. Interaction of the tick immune system with transmitted pathogens. Front Cell Infect Microbiol. 2013;3:26.

51. Cerenius L, Söderhäll K. The prophenoloxidase-activating system in invertebrates. Immunol Rev. 2004;198:116-26.

52. Kim CH, Paik D, Rus F, Silverman N. The caspase-8 homolog Dredd cleaves Imd and Relish but is not inhibited by p35. J Biol Chem. 2014;289(29): 20092-101.

53. Souza-Neto JA, Sim S, Dimopoulos G. An evolutionary conserved function of the JAK-STAT pathway in anti-dengue defense. Proc Natl Acad Sci USA. 2009;106(42):17841-6.

54. Barillas-Mury C, Han YS, Seeley D, Kafatos FC. Anopheles gambiae Ag-STAT, a new insect member of the STAT family, is activated in response to bacterial infection. EMBO J. 1999:18(4):959-67.

55. Gupta L, Molina-Cruz A, Kumar S, Rodrigues J, Dixit R, Zamora RE, et al. The STAT pathway mediates late-phase immunity against Plasmodium in the mosquito Anopheles gambiae. Cell Host Microbe. 2009:5(5):498-507.

56. Liu L, Dai J, Zhao YO, Narasimhan S, Yang Y, Zhang L, et al. Ixodes scapularis JAK-STAT pathway regulates tick antimicrobial peptides, thereby controlling the agent of human granulocytic anaplasmosis. J Infect Dis. 2012;206(8): 1233-41.

57. Bahia AC, Kubota MS, Tempone AJ, Araújo HR, Guedes BA, Orfanó AS, et al. The JAK-STAT pathway controls Plasmodium vivax load in early stages of Anopheles aquasalis infection. PLoS Negl Trop Dis. 2011;5(11), e1317.
58. Christensen BM, Li J, Chen CC, Nappi AJ. Melanization immune responses in mosquito vectors. Trends Parasitol. 2005;21(4):192-9.

59. Cerenius L, Lee BL, Söderhäll K. The proPO-system: pros and cons for its role in invertebrate immunity. Trends Immunol. 2008;29(6):263-71.

60. Watson FL, Püttmann-Holgado R, Thomas F, Lamar DL, Hughes M, Kondo $M$, et al. Extensive diversity of lg-superfamily proteins in the immune system of insects. Science. 2005;309(5742):1874-8.

61. Dong Y, Taylor HE, Dimopoulos G. AgDscam, a hypervariable immunoglobulin domain-containing receptor of the Anopheles gambiae innate immune system. PLoS Biol. 2006;4(7), e229.

62. Armitage SA, Freiburg RY, Kurtz J, Bravo IG. The evolution of Dscam genes across the arthropods. BMC Evol Biol. 2012;12:53.

63. Rowley AF, Powell A. Invertebrate immune systems specific, quasi-specific, or nonspecific? J Immunol. 2007;179(11):7209-14.

64. Garcia ES, Castro DP, Figueiredo MB, Genta FA, Azambuja P. Trypanosoma rangeli: a new perspective for studying the modulation of immune reactions of Rhodnius prolixus. Parasit Vectors. 2009;2(1):33.

65. Sojka D, Franta Z, Horn M, Hajdusek O, Caffrey CR, Mares M, et al. Profiling of proteolytic enzymes in the gut of the tick Ixodes ricinus reveals an evolutionarily conserved network of aspartic and cysteine peptidases. Parasit Vectors. 2008;1(1):7.

66. Franta Z, Frantová H, Konvičková J, Horn M, Sojka D, Mareš M, et al. Dynamics of digestive proteolytic system during blood feeding of the hard tick Ixodes ricinus. Parasit Vectors. 2010;3:119.

67. Franta Z, Sojka D, Frantova H, Dvorak J, Horn M, Srba J, et al. IrCL1 - the haemoglobinolytic cathepsin L of the hard tick, Ixodes ricinus. Int J Parasitol. 2011:41(12):1253-62.

68. Sojka D, Hajdusek O, Dvorák J, Sajid M, Franta Z, Schneider EL, et al. IrAE: an asparaginyl endopeptidase (legumain) in the gut of the hard tick Ixodes ricinus. Int J Parasitol. 2007;37(7):713-24.

69. Yamaji K, Tsuji N, Miyoshi T, Islam MK, Hatta T, Alim MA, et al. Hemoglobinase activity of a cysteine protease from the ixodid tick Haemaphysalis longicornis. Parasitol Int. 2009;58(3):232-7.

70. Mulenga A, Sugimoto C, Ingram G, Ohashi K, Onuma M. Molecular cloning of two Haemaphysalis longicornis cathepsin L-like cysteine proteinase genes. J Vet Med Sci. 1999;61(5):497-502.

71. Mendiola J, Alonso M, Marquetti MC, Finlay C. Boophilus microplus: multiple proteolytic activities in the midgut. Exp Parasitol. 1996;82(1): 27-33.

72. Renard G, Garcia JF, Cardoso FC, Richter MF, Sakanari JA, Ozaki LS, et al. Cloning and functional expression of a Boophilus microplus cathepsin L-like enzyme. Insect Biochem Mol Biol. 2000;30(11):1017-26.

73. Renard G, Lara FA, de Cardoso FC, Miguens FC, Dansa-Petretski M, Termignoni $C_{\text {, et }}$ al. Expression and immunolocalization of a Boophilus microplus cathepsin L-like enzyme. Insect Mol Biol. 2002; 11(4):325-8.

74. Estrela AB, Seixas A, Teixeira VO, Pinto AF, Termignoni C. Vitellin- and hemoglobin-digesting enzymes in Rhipicephalus (Boophilus) microplus larvae and females. Comp Biochem Physiol B Biochem Mol Biol. 2010; 157(4):326-35.

75. Estrela A, Seixas A, Termignoni C. A cysteine endopeptidase from tick (Rhipicephalus (Boophilus) microplus) larvae with vitellin digestion activity. Comp Biochem Physiol B Biochem Mol Biol. 2007;148(4):410-6.

76. Seixas A, Dos Santos PC, Velloso FF, Da Silva VI, Masuda A, Horn F, et al. A Boophilus microplus vitellin-degrading cysteine endopeptidase. Parasitology. 2003;126(2):155-63.

77. Seixas A, Estrela AB, Ceolato JC, Pontes EG, Lara F, Gondim KC, et al. Localization and function of Rhipicephalus (Boophilus) microplus vitellindegrading cysteine endopeptidase. Parasitology. 2010;137(12):1819-31.

78. Oldiges DP, Parizi LF, Zimmer KR, Lorenzini DM, Seixas A, Masuda A, et al. A Rhipicephalus (Boophilus) microplus cathepsin with dual peptidase and antimicrobial activity. Int J Parasitol. 2012;42(7):635-45.

79. Moolhuijzen PM, Lew-Tabor AE, Morgan JA, Valle MR, Peterson DG, Dowd $\mathrm{SE}$, et al. The complexity of Rhipicephalus (Boophilus) microplus genome characterised through detailed analysis of two BAC clones. BMC Res Notes. 2011:4:254.

80. Tsuji N, Miyoshi T, Battsetseg B, Matsuo T, Xuan X, Fujisaki K. A cysteine protease is critical for Babesia spp. transmission in Haemaphysalis ticks. PLoS Pathog. 2008;4(5):e1000062.

81. Abdul Alim M, Tsuji N, Miyoshi T, Khyrul Islam M, Huang X, Motobu M, et al. Characterization of asparaginyl endopeptidase, legumain induced by blood 
feeding in the ixodid tick Haemaphysalis longicornis. Insect Biochem Mol Biol. 2007;37(9):911-22.

82. Alim MA, Tsuji N, Miyoshi T, Islam MK, Huang X, Hatta T, et al. HILgm2, a member of asparaginyl endopeptidases/legumains in the midgut of the ixodid tick Haemaphysalis longicornis, is involved in blood-meal digestion. J Insect Physiol. 2008;54(3):573-85.

83. Alim MA, Tsuji N, Miyoshi T, Islam MK, Hatta T, Fujisaki K. Legumains from the hard tick Haemaphysalis longicornis play modulatory roles in blood feeding and gut cellular remodelling and impact on embryogenesis. Int J Parasitol. 2009:39(1):97-107.

84. Sojka D, Franta Z, Frantová H, Bartosová P, Horn M, Váchová J, et al. Characterization of gut-associated cathepsin $D$ hemoglobinase from tick Ixodes ricinus (IrCD1). J Biol Chem. 2012;287(25):21152-63.

85. Sojka D, Hartmann D, Bartošová-Sojková P, Dvořák J. Parasite cathepsin Dlike peptidases and their relevance as therapeutic targets. Trends Parasitol. 2016;32(9):708-23.

86. Logullo C, Vaz Ida S, Sorgine MH, Paiva-Silva GO, Faria FS, Zingali RB, et al. Isolation of an aspartic proteinase precursor from the egg of a hard tick, Boophilus microplus. Parasitology. 1998;1 16(6):525-32.

87. Abreu LA, Valle D, Manso PP, Façanha AR, Pelajo-Machado M, Masuda H, et al. Proteolytic activity of Boophilus microplus Yolk pro-Cathepsin D (BYC) is coincident with cortical acidification during embryogenesis. Insect Biochem Mol Biol. 2004;34(5):443-9.

88. Sorgine MH, Logullo C, Zingali RB, Paiva-Silva GO, Juliano L, Oliveira PL. A heme-binding aspartic proteinase from the eggs of the hard tick Boophilus microplus. J Biol Chem. 2000;275(37):28659-65.

89. Cruz CE, Fogaça AC, Nakayasu ES, Angeli CB, Belmonte R, Almeida IC, et al. Characterization of proteinases from the midgut of Rhipicephalus (Boophilus) microplus involved in the generation of antimicrobial peptides. Parasit Vectors. 2010;3:63.

90. Boldbaatar D, Sikalizyo Sikasunge C, Battsetseg B, Xuan X, Fujisaki K. Molecular cloning and functional characterization of an aspartic protease from the hard tick Haemaphysalis longicornis. Insect Biochem Mol Biol. 2006; 36(1):25-36.

91. Urbanová V, Hartmann D, Grunclová L, Šíma R, Flemming T, Hajdušek O, et al. IrFC - An Ixodes ricinus injury-responsive molecule related to Limulus Factor C. Dev Comp Immunol. 2014;46(2):439-47.

92. Liu LM, Liu JN, Liu Z, Yu ZJ, Xu SQ, Yang XH, et al. Microbial communities and symbionts in the hard tick Haemaphysalis longicornis (Acari: Ixodidae) from north China. Parasit Vectors. 2013;6(1):310.

93. Mulenga A, Sugimoto C, Ingram G, Ohashi K, Misao O. Characterization of two cDNAs encoding serine proteinases from the hard tick Haemaphysalis longicornis. Insect Biochem Mol Biol. 2001;31(8):817-25.

94. Miyoshi T, Tsuji N, Islam MK, Kamio T, Fujisaki K. Cloning and molecular characterization of a cubilin-related serine proteinase from the hard tick Haemaphysalis longicornis. Insect Biochem Mol Biol. 2004;34(8):799-808.

95. Miyoshi T, Tsuji N, Islam MK, Huang X, Motobu M, Alim MA, et al. Molecular and reverse genetic characterization of serine proteinase-induced hemolysis in the midgut of the ixodid tick Haemaphysalis longicornis. I Insect Physiol. 2007;53(2):195-203.

96. Bork P, Beckmann G. The CUB domain. A widespread module in developmentally regulated proteins. J Mol Biol. 1993;231(2):539-45.

97. Miyoshi T, Tsuji N, Islam MK, Alim MA, Hatta T, Huang X, et al. A set of serine proteinase paralogs are required for blood-digestion in the ixodid tick Haemaphysalis longicornis. Parasitol Int. 2008;57(4):499-505.

98. Motobu M, Tsuji N, Miyoshi T, Huang X, Islam MK, Alim MA, et al. Molecular characterization of a blood-induced serine carboxypeptidase from the ixodid tick Haemaphysalis longicornis. FEBS J. 2007;274(13):3299-312.

99. Mulenga A, Erikson K. A snapshot of the Ixodes scapularis degradome. Gene. 2011:482(1-2):78-93.

100. Anderson JM, Sonenshine DE, Valenzuela JG. Exploring the mialome of ticks: an annotated catalogue of midgut transcripts from the hard tick, Dermacentor variabilis (Acari: Ixodidae). BMC Genomics. 2008;9:552.

101. Hatta T, Kazama K, Miyoshi T, Umemiya R, Liao M, Inoue N, et al. Identification and characterisation of a leucine aminopeptidase from the hard tick Haemaphysalis longicornis. Int J Parasitol. 2006;36(10-11):1123-32.

102. Xu XL, Cheng TY, Yang H, Yan F, Yang Y. De novo sequencing, assembly and analysis of salivary gland transcriptome of Haemaphysalis flava and identification of sialoprotein genes. Infect Genet Evol. 2015;32:135-42.

103. Barnard AC, Nijhof AM, Gaspar AR, Neitz AW, Jongejan F, Maritz-Olivier C. Expression profiling, gene silencing and transcriptional networking of metzincin metalloproteases in the cattle tick, Rhipicephalus (Boophilus) microplus. Vet Parasitol. 2012;186(3-4):403-14.

104. Radulović Ž, Kim TK, Porter LM, Sze SH, Lewis L, Mulenga A. A 24-48 h fed Amblyomma americanum tick saliva immuno-proteome. BMC Genomics. 2014;15:518.

105. Masaki T. Historical review: Endothelin. Trends Pharmacol Sci. 2004;25(4): 219-24.

106. Decrem Y, Mariller M, Lahaye K, Blasioli V, Beaufays J, Zouaoui Boudjeltia K, et al. The impact of gene knock-down and vaccination against salivary metalloproteases on blood feeding and egg laying by Ixodes ricinus. Int J Parasitol. 2008;38(5):549-60.

107. Imamura S, da Silva VI, Konnai S, Yamada S, Nakajima C, Onuma M, et al. Effect of vaccination with a recombinant metalloprotease from Haemaphysalis longicornis. Exp Appl Acarol. 2009;48(4):345-58.

108. Ali A, Tirloni L, Isezaki M, Seixas A, Konnai S, Ohashi K, et al. Reprolysin metalloproteases from Ixodes persulcatus, Rhipicephalus sanguineus and Rhipicephalus microplus ticks. Exp Appl Acarol. 2014;63(4):559-78.

109. Waniek PJ, Pacheco Costa JE, Jansen AM, Costa J, Araújo CA. Cathepsin L of Triatoma brasiliensis (Reduviidae, Triatominae): sequence characterization, expression pattern and zymography. J Insect Physiol. 2012;58(1):178-87.

110. Lopez-Ordoñez T, Rodriguez MH, Hernández-Hernández FD. Characterization of a cDNA encoding a cathepsin L-like protein of Rhodnius prolixus. Insect Mol Biol. 2001;10(5):505-11.

111. Kollien AH, Waniek PJ, Nisbet AJ, Billingsley PF, Schaub GA. Activity and sequence characterization of two cysteine proteases in the digestive tract of the reduviid bug Triatoma infestans. Insect Mol Biol. 2004;13(6):569-79.

112. Houseman JG, Downe A. Activity cycles and the control of four digestive proteinases in the posterior midgut of Rhodnius prolixus Stål (Hemiptera: Reduviidae). J Insect Physiol. 1983;29(2):141-8.

113. Billingsley PF, Downe AE. The effects of artificial diets on the anterior intestinal cell ultrastructure of Rhodnius prolixus (Hemiptera: Reduviidae). Int J Parasitol. 1989:19(3):291-9.

114. Borges EC, Machado EM, Garcia ES, Azambuja P. Trypanosoma cruzi: effects of infection on cathepsin $D$ activity in the midgut of Rhodnius prolixus. Exp Parasitol. 2006;112(2):130-3.

115. Buarque DS, Braz GR, Martins RM, Tanaka-Azevedo AM, Gomes CM, Oliveira FA, et al. Differential expression profiles in the midgut of Triatoma infestans infected with Trypanosoma cruzi. PLoS One. 2013;8(5), e61203.

116. Balczun C, Siemanowski J, Pausch JK, Helling S, Marcus K, Stephan C, et al. Intestinal aspartate proteases TiCatD and TiCatD2 of the haematophagous bug Triatoma infestans (Reduviidae): sequence characterisation, expression pattern and characterisation of proteolytic activity. Insect Biochem Mol Biol. 2012;42(4):240-50

117. Ribeiro JM, Genta FA, Sorgine MH, Logullo R, Mesquita RD, Paiva-Silva GO, et al. An insight into the transcriptome of the digestive tract of the bloodsucking bug, Rhodnius prolixus. PLoS Negl Trop Dis. 2014;8(1), e2594.

118. Leyria J, Fruttero LL, Nazar M, Canavoso LE. The role of DmCatD, a cathepsin D-like peptidase, and acid phosphatase in the process of follicular atresia in Dipetalogaster maxima (Hemiptera: Reduviidae), a vector of Chagas' disease. PLoS One. 2015;10(6), e0130144.

119. Gaboriaud C, Gregory-Pauron L, Teillet F, Thielens NM, Bally I, Arlaud GJ. Structure and properties of the $\mathrm{Ca}(2+)$-binding CUB domain, a widespread ligand-recognition unit involved in major biological functions. Biochem J. 2011;439(2):185-93.

120. Schwarz A, Medrano-Mercado N, Schaub GA, Struchiner CJ, Bargues MD, Levy $M Z$, et al. An updated insight into the sialotranscriptome of Triatoma infestans: developmental stage and geographic variations. PLoS Negl Trop Dis. 2014;8(12), e3372.

121. Feder D, Salles JM, Garcia ES, Azambuja P. Haemolymph and fat body metalloprotease associated with Enterobacter cloacae infection in the bloodsucking insect, Rhodnius prolixus. Mem Inst Oswaldo Cruz. 1998;93(6):823-6.

122. Feder D, Gomes S, Garcia E, Azambuja P. Metalloproteases in Trypanosoma rangeli-infected Rhodnius prolixus. Mem Inst Oswaldo Cruz. 1999;94(6):771-7.

123. Assumpção TC, Eaton DP, Pham VM, Francischetti IM, Aoki V, Hans-Filho G, et al. An insight into the sialotranscriptome of Triatoma matogrossensis, a kissing bug associated with fogo selvagem in South America. Am J Trop Med Hyg. 2012;86(6):1005-14.

124. da Silveira RB, dos Santos Filho JF, Mangili OC, Veiga SS, Gremski W, Nader $H B$, et al. Identification of proteases in the extract of venom glands from brown spiders. Toxicon. 2002;40(6):815-22. 
125. Feitosa L, Gremski W, Veiga SS, Elias MC, Graner E, Mangili OC, et al. Detection and characterization of metalloproteinases with gelatinolytic, fibronectinolytic and fibrinogenolytic activities in brown spider (Loxosceles intermedia) venom. Toxicon. 1998;36(7):1039-51.

126. da Silveira RB, Wille AC, Chaim OM, Appel MH, Silva DT, Franco CR, et al. Identification, cloning, expression and functional characterization of an astacin-like metalloprotease toxin from Loxosceles intermedia (brown spider) venom. Biochem J. 2007;406(2):355-63.

127. Trevisan-Silva D, Gremski LH, Chaim OM, da Silveira RB, Meissner GO, Mangili OC, et al. Astacin-like metalloproteases are a gene family of toxins present in the venom of different species of the brown spider (genus Loxosceles). Biochimie. 2010;92(1):21-32.

128. Hsu CC, Wu WB, Chang YH, Kuo HL, Huang TF. Antithrombotic effect of a protein-type I class snake venom metalloproteinase, kistomin, is mediated by affecting glycoprotein Ib-von Willebrand factor interaction. Mol Pharmacol. 2007;72(4):984-92.

129. Huang TF, Chang MC, Teng CM. Antiplatelet protease, kistomin, selectively cleaves human platelet glycoprotein Ib. Biochim Biophys Acta. 1993;1158(3): 293-9.

130. Hsu CC, Wu WB, Huang TF. A snake venom metalloproteinase, kistomin, cleaves platelet glycoprotein VI and impairs platelet functions. J Thromb Haemost. 2008;6(9):1578-85.

131. Cho WL, Tsao SM, Hays AR, Walter R, Chen JS, Snigirevskaya ES, et al. Mosquito cathepsin B-like protease involved in embryonic degradation of vitellin is produced as a latent extraovarian precursor. J Biol Chem. 1999; 274(19):13311-21.

132. Edgar KA, Noriega FG, Bonning BC, Wells MA. Recombinant juvenile hormone esterase, an effective tool for modifying juvenile hormonedependent expression of the early trypsin gene in mosquitoes. Insect Mol Biol. 2000;9(1):27-31.

133. Noriega FG, Pennington JE, Barillas-Mury C, Wang XY, Wells MA. Aedes aegypti midgut early trypsin is post-transcriptionally regulated by blood feeding. Insect Mol Biol. 1996;5(1):25-9.

134. Noriega FG, Wang XY, Pennington JE, Barillas-Mury CV, Wells MA. Early trypsin, a female-specific midgut protease in Aedes aegypti: isolation aminoterminal sequence determination, and cloning and sequencing of the gene. Insect Biochem Mol Biol. 1996;26(2):119-26.

135. Barillas-Mury CV, Noriega FG, Wells MA. Early trypsin activity is part of the signal transduction system that activates transcription of the late trypsin gene in the midgut of the mosquito, Aedes aegypti. Insect Biochem Mol Biol. 1995;25(2):241-6.

136. Brandon MC, Pennington JE, Isoe J, Zamora J, Schillinger AS, Miesfeld RL. TOR signaling is required for amino acid stimulation of early trypsin protein synthesis in the midgut of Aedes aegypti mosquitoes. Insect Biochem Mol Biol. 2008:38(10):916-22.

137. Rascón AA, Gearin J, Isoe J, Miesfeld RL. In vitro activation and enzyme kinetic analysis of recombinant midgut serine proteases from the Dengue vector mosquito Aedes aegypti. BMC Biochem. 2011;12:43.

138. Isoe J, Rascón AA, Kunz S, Miesfeld RL. Molecular genetic analysis of midgut serine proteases in Aedes aegypti mosquitoes. Insect Biochem Mol Biol. 2009:39(12):903-12.

139. Brackney DE, Isoe J, W C B, Zamora J, Foy BD, Miesfeld RL, et al. Expression profiling and comparative analyses of seven midgut serine proteases from the yellow fever mosquito, Aedes aegypti. J Insect Physiol. 2010;56(7):736-44

140. Müller HM, Crampton JM, della Torre A, Sinden R, Crisanti A. Members of a trypsin gene family in Anopheles gambiae are induced in the gut by blood meal. EMBO J. 1993;12(7):2891-900.

141. Nirmala X, Marinotti $O$, James AA. The accumulation of specific mRNAs following multiple blood meals in Anopheles gambiae. Insect Mol Biol. 2005; 14(1):95-103.

142. Müller HM, Catteruccia F, Vizioli J, della Torre A, Crisanti A. Constitutive and blood meal-induced trypsin genes in Anopheles gambiae. Exp Parasitol. 1995:81(3):371-85.

143. Dias-Lopes G, Borges-Veloso A, Saboia-Vahia L, Domont GB, Britto C, Cuervo $P$, et al. Expression of active trypsin-like serine peptidases in the midgut of sugar-feeding female Anopheles aquasalis. Parasit Vectors. 2015; 8:296.

144. Graf R, Raikhel AS, Brown MR, Lea AO, Briegel H. Mosquito trypsin: immunocytochemical localization in the midgut of blood-fed Aedes aegypti (L.). Cell Tissue Res. 1986;245(1):19-27.
145. Graf R, Boehlen P, Briegel H. Structural diversity of trypsin from different mosquito species feeding on vertebrate blood. Experientia. 1991;47(6):603-9.

146. Borges-Veloso A, Saboia-Vahia L, Dias-Lopes G, Domont GB, Britto C, Cuervo $P$, et al. In-depth characterization of trypsin-like serine peptidases in the midgut of the sugar fed Culex quinquefasciatus. Parasit Vectors. 2015:8:373.

147. Bian G, Raikhel AS, Zhu J. Characterization of a juvenile hormone-regulated chymotrypsin-like serine protease gene in Aedes aegypti mosquito. Insect Biochem Mol Biol. 2008;38(2):190-200.

148. Jiang Q, Hall M, Noriega FG, Wells M. cDNA cloning and pattern of expression of an adult, female-specific chymotrypsin from Aedes aegypti midgut. Insect Biochem Mol Biol. 1997;27(4):283-9.

149. Saboia-Vahia L, Cuervo P, Borges-Veloso A, de Souza NP, Britto C, Dias-Lopes $\mathrm{G}$, et al. The midgut of Aedes albopictus females expresses active trypsin-like serine peptidases. Parasit Vectors. 2014;7:253.

150. Vizioli J, Catteruccia F. della Torre A, Reckmann I, Müller HM. Blood digestion in the malaria mosquito Anopheles gambiae: molecular cloning and biochemical characterization of two inducible chymotrypsins. Eur J Biochem. 2001;268(14): 4027-35.

151. Shen Z, Edwards MJ, Jacobs-Lorena M. A gut-specific serine protease from the malaria vector Anopheles gambiae is downregulated after blood ingestion. Insect Mol Biol. 2000;9(3):223-9.

152. de Almeida RW, Tovar FJ, Ferreira II, Leoncini O. Chymotrypsin genes in the malaria mosquitoes Anopheles aquasalis and Anopheles darlingi. Insect Biochem Mol Biol. 2003;33(3):307-15.

153. Dimopoulos G, Richman A, Müller HM, Kafatos FC. Molecular immune responses of the mosquito Anopheles gambiae to bacteria and malaria parasites. Proc Natl Acad Sci USA. 1997;94(21):11508-13.

154. Dimopoulos G, Richman A. della Torre A, Kafatos FC, Louis C. Identification and characterization of differentially expressed cDNAs of the vector mosquito, Anopheles gambiae. Proc Natl Acad Sci USA. 1996;93(23):13066-71.

155. Paskewitz SM, Reese-Stardy S, Gorman MJ. An easter-like serine protease from Anopheles gambiae exhibits changes in transcript abundance following immune challenge. Insect Mol Biol. 1999;8(3):329-37.

156. Gorman MJ, Andreeva OV, Paskewitz SM. Molecular characterization of five serine protease genes cloned from Anopheles gambiae hemolymph. Insect Biochem Mol Biol. 2000;30(1):35-46.

157. Gorman MJ, Andreeva OV, Paskewitz SM. Sp22D: a multidomain serine protease with a putative role in insect immunity. Gene. 2000;251(1):9-17.

158. Sriwichai P, Rongsriyam Y, Jariyapan N, Apiwathnasorn C, Sattabongkot J, Paskewitz S. Expression of three serine protease genes from the South East Asian malaria vector, Anopheles dirus, in relation to blood feeding and parasite infection. Dev Comp Immunol. 2008;32(9):1011-4.

159. Noriega FG, Edgar KA, Bechet R, Wells MA. Midgut exopeptidase activities in Aedes aegypti are induced by blood feeding. J Insect Physiol. 2002;48(2): 205-12.

160. Goulielmaki E, Sidén-Kiamos I, Loukeris TG. Functional characterization of Anopheles matrix metalloprotease 1 reveals its agonistic role during sporogonic development of malaria parasites. Infect Immun. 2014;82(11): 4865-77.

161. Okamoto T, Akaike T, Sawa T, Miyamoto Y, van der Vliet A, Maeda $H$. Activation of matrix metalloproteinases by peroxynitrite-induced protein S-glutathiolation via disulfide S-oxide formation. J Biol Chem. 2001;276(31): 29596-602.

162. Okamoto T, Akuta T, Tamura F, van Der Vliet A, Akaike T. Molecular mechanism for activation and regulation of matrix metalloproteinases during bacterial infections and respiratory inflammation. Biol Chem. 2004; 385(11):997-1006.

163. Cho WL, Raikhel AS. Cloning of cDNA for mosquito lysosomal aspartic protease. Sequence analysis of an insect lysosomal enzyme similar to cathepsins D and E. J Biol Chem. 1992;267(30):21823-9.

164. Ramalho-Ortigão JM, Kamhawi S, Rowton ED, Ribeiro JM, Valenzuela JG. Cloning and characterization of trypsin- and chymotrypsin-like proteases from the midgut of the sand fly vector Phlebotomus papatasi. Insect Biochem Mol Biol. 2003:33(2):163-71.

165. Telleria EL, Pitaluga AN, Ortigão-Farias JR, de Araújo AP, Ramalho-Ortigão JM, Traub-Cseko YM. Constitutive and blood meal-induced trypsin genes in Lutzomyia longipalpis. Arch Insect Biochem Physiol. 2007;66(2):53-63.

166. Telleria EL, de Araújo AP, Secundino NF, d'Avila-Levy CM, Traub-Csekö YM. Trypsin-like serine proteases in Lutzomyia longipalpis-expression, activity and possible modulation by Leishmania infantum chagasi. PLoS One. 2010; 5(5):e10697. 
167. Borovsky D, Schlein Y. Trypsin and chymotrypsin-like enzymes of the sandfly Phlebotomus papatasi infected with Leishmania and their possible role in vector competence. Med Vet Entomol. 1987;1(3):235-42.

168. Pimenta PF, Modi GB, Pereira ST, Shahabuddin M, Sacks DL. A novel role for the peritrophic matrix in protecting Leishmania from the hydrolytic activities of the sand fly midgut. Parasitology. 1997;115(Pt4):359-69.

169. Schlein Y, Jacobson RL. Resistance of Phlebotomus papatasi to infection with Leishmania donovani is modulated by components of the infective bloodmeal. Parasitology. 1998;117(Pt5):467-73.

170. Ruttayaporn N, Zhou M, Suganuma K, Yamasaki S, Kawazu S, Inoue N. Expression and characterization of cathepsin B from tsetse (Glossina morsitans morsitans). Jpn J Vet Res. 2013;619(4):137-47.

171. Ribeiro JM. Blood-feeding arthropods: live syringes or invertebrate pharmacologists? Infect Agents Dis. 1995;4(3):143-52.

172. R. Kini M, J. Clemetson K, S. Markland F, McLane MA, Morita T. Toxins and Hemostasis. From Bench to Bedside. New York: Springer; 2010.

173. Delcroix M, Sajid M, Caffrey CR, Lim KC, Dvorák J, Hsieh I, et al. A multienzyme network functions in intestinal protein digestion by a platyhelminth parasite. J Biol Chem. 2006;281(51):39316-29.

174. Williamson AL, Brindley PJ, Knox DP, Hotez PJ, Loukas A. Digestive proteases of blood-feeding nematodes. Trends Parasitol. 2003;19(9):417-23.

175. da Silva DS, de Oliveira CF, Parra JR, Marangoni S, Macedo ML. Short and long-term antinutritional effect of the trypsin inhibitor ApTI for biological control of sugarcane borer. J Insect Physiol. 2014;61:1-7.

\section{Submit your next manuscript to BioMed Central and we will help you at every step:}

- We accept pre-submission inquiries

- Our selector tool helps you to find the most relevant journal

- We provide round the clock customer support

- Convenient online submission

- Thorough peer review

- Inclusion in PubMed and all major indexing services

- Maximum visibility for your research

Submit your manuscript at www.biomedcentral.com/submit

) Biomed Central 